\title{
The Relationship between Climate Change, Variability, and Food Security: Understanding the Impacts and Building Resilient Food Systems in West Pokot County, Kenya
}

\author{
Everlyne B. Obwocha ${ }^{1, * \mathbb{D}}$, Joshua J. Ramisch ${ }^{2} \mathbb{D}$, Lalisa Duguma ${ }^{1} \mathbb{D}$ and Levi Orero ${ }^{1(D)}$ \\ 1 World Agroforestry (ICRAF), P.O. Box 30766-00100, Nairobi 00100, Kenya; \\ 1.a.duguma@cgiae.org (L.D.); 1.orero@cgiar.org (L.O.) \\ 2 School of International Development and Global Studies, University of Ottawa, \\ Ottawa, ON K1N 6N5, Canada; jramisch@uottawa.ca \\ * Correspondence: everlynbinyanya@gmail.com
}

check for updates

Citation: Obwocha, E.B.; Ramisch, J.J.; Duguma, L.; Orero, L. The Relationship between Climate Change, Variability, and Food Security: Understanding the Impacts and Building Resilient Food Systems in West Pokot County, Kenya. Sustainability 2022, 14, 765. https://doi.org/10.3390/ su14020765

Academic Editor: Hossein Azadi

Received: 6 October 2021

Accepted: 10 December 2021

Published: 11 January 2022

Publisher's Note: MDPI stays neutral with regard to jurisdictional claims in published maps and institutional affiliations.

Copyright: (C) 2022 by the authors. Licensee MDPI, Basel, Switzerland. This article is an open access article distributed under the terms and conditions of the Creative Commons Attribution (CC BY) license (https:/ / creativecommons.org/licenses/by/ $4.0 /)$.

\begin{abstract}
This study integrated local and scientific knowledge to assess the impacts of climate change and variability on food security in West Pokot County, Kenya from 1980-2012. It characterized rainfall and temperature from 1980-2011 and the phenology of agricultural vegetation, assessed land use and land cover (LULC) changes, and surveyed local knowledge and perceptions of the relationships between climate change and variability, land use decisions, and food (in)security. The 124 respondents were aware of long-term changes in their environment, with $68 \%$ strongly believing that climate has become more variable. The majority of the respondents $(88 \%)$ reported declining rainfall and rising temperatures, with respondents in the lowland areas reporting shortened growing seasons that affected food production. Meteorological data for 1980-2011 confirmed high inter-annual rainfall variability around the mean value of $973.4 \mathrm{~mm} / \mathrm{yr}$ but with no notable trend. Temperature data showed an increasing trend between 1980 and 2012 with lowlands and highlands showing changes of $+1.25^{\circ} \mathrm{C}$ and $+1.29^{\circ} \mathrm{C}$, respectively. Land use and land cover changes between 1984 and 2010 showed cropland area increased by $+4176 \%(+33,138 \mathrm{ha})$, while grassland and forest areas declined by $-49 \%$ ( $-96,988$ ha) and $-38 \%$ ( $-65,010$ ha), respectively. These area changes illustrate human-mediated responses to the rainfall variability, such as increased stocking after good rainfall years and crop area expansion. The mean Normalized Difference Vegetation Index (NDVI) values ranged from 0.36-0.54 within a year, peaking in May and September. For weather-related planning, respondents relied on radio $(64 \%)$ and traditional forecasters $(26 \%)$ as predominant information sources. Supporting continuous climate change monitoring, intensified early warning systems, and disseminating relevant information to farmers could help farmers adopt appropriate adaptation strategies.
\end{abstract}

Keywords: climate change; Kenya; variability; food security; West Pokot

\section{Introduction}

Climate variability and change are a significant threat to food security in Africa and many regions of the developing world, which are largely dependent on rain-fed agriculture [1-4] and, hence, highly sensitive to changes in rainfall patterns. The agriculturebased economies of Africa [5,6] and Asia [7,8] remain reliant on smallholder farming households. Understanding and adapting the knowledge these farmers have of their environments $[9,10]$ to the prediction of the effects of climate change and variability on agricultural systems will be one of the biggest challenges of the current century [11]. The complexity of African agro-ecologies, coupled with a lack of long-term rainfall data from the past century in many African regions, makes it hard to state any conclusions about annual precipitation trends during this time [12]. This has set limits for food production [13], with negative consequences for farmers in terms of their food security and livelihood across the world, especially in developing countries [2,13-15]. Neufeldt et al. [16] explained that 
climate change would cause a rise in temperature and change in precipitation patterns, negatively affecting global food production. Such impacts have altered potential crop yield through short-term crop failures and long-term production declines [17], hence, increasing vulnerabilities for smallholder farmers in developing countries [18].

Climate change affects all dimensions of food security (food availability, food accessibility, food utilization, and food system stability), thus, impacting human health, livelihood assets, food production and distribution, and markets [14]. The Food and Agricultural Organization (FAO) defines food security as a situation that exists when people have secure access to sufficient amounts of safe and nutritious food for normal growth, development, and an active and healthy life [14]. However, the major challenge of the 21st century is to achieve food security under marked shifts in climatic risks while using environmentally sound farming practices [19]. The 21st century in particular, is predicted to be the warmest so far [20]. As indicated by Arndt et al. [21], approximately 223 million people are currently undernourished in SSA, and the effects of climate change will increase that number up to 355 million people by 2050 .

Like many SSA nations, Kenya has suffered incidences of food deficit. Incidences of prolonged droughts and unexpected changes in normal weather patterns in past years have affected food security, particularly in vulnerable parts of Kenya [22]. This has, in turn, claimed human lives, decimated livestock, and reduced farm output [23,24]. In 2009, over 3.5 million Kenyans faced severe food shortages when failed rainfall seasons led to intense drought [25], which produced a general crop harvest failure [3]. The situation has worsened, and the frequency with which the country experiences cyclical food crises has reduced from 20 years (1964-1984) to 12 years (1984-1996), to 2 years (2004-2006), to yearly (2007/2008/2009/2010/2011/2012) [26]. Wakibi et al. [27] show that 30 percent of Kenyan households are food insecure, which means they do not have access to sufficient food to sustain an active and, healthy life for all household members. USAID [24] has also indicated that approximately one-third of Kenya's population is food insecure. According to the Food Security Index of the World Food Program, a report by Ng'ang'a [28] listed Kenya among the 15 countries prone to food insecurity. Despite these uncertainties, Kenya should aim to achieve food security and end hunger in the face of the ongoing impacts of climate change and variability as it is core to the Sustainable Development Goals.

West Pokot County is one of the food deficient and food insecure counties in Kenya [23]. As a semi-arid region, the county experiences a highly variable climate, such as drought and unpredictable rainfall patterns, but existing research on the resulting food insecurity and related humanitarian disasters has largely treated local populations as victims rather than agents of potential change (e.g., [23]). Most previous studies in Kenya indicate that the impact of climate change on crop and livestock productivity has ambiguous and complex impacts on food security that require local parameterisation $[29,30]$. Studies have established that undertaking climate change impact assessments on a local scale is essential as it allows the exploration of local agronomic management practices and their incorporation into adaptation strategies formulation [31,32]. Indeed, given an existing context of substantial variability and uncertainty in most Kenyan production systems (e.g., of rainfall, temperature), it is increasingly apparent that adaptation measures will not be adopted without building upon how local people perceive and respond to longterm processes of climate change [29]. This study addresses this gap by using West Pokot as a case study to demonstrate how the ambiguous temperature and rainfall data for the county nevertheless account for clear land use and land cover changes, which can be meaningfully interpreted using the local population's understandings of climate and food security outcomes. Integrating these complex knowledge systems is essential for designing and implementing successful adaptation interventions [33,34] and for climate risk management [35-37].

Remote sensing data provides largely unexploited opportunities in agriculture to assess land use and crop growth on parcel, farm, and regional scales [38]. Land use and land cover (LULC) change is, therefore, central to food security assessments and this 
study contributes to understanding the role of land use in the sustainability of global food systems amid climate change effects. According to Darkoh [39], the rapidly accelerating change in the landscape is associated with a wide variety of issues, including declining biodiversity, global climate change, food security, and land degradation, which applies to soils, vegetation, and water depletion. The Normalized Difference Vegetation Index (NDVI) variations in both space and time scales that can be assessed remotely, are important for illustrating vegetation-climate feedback mechanisms at varying crop stages, which can assist policy makers with proactive and reactive risk measurements [40-43]. This is especially relevant for West Pokot County where systematic data of such relationships is lacking. This sort of data can be applied for the identification of crop species and soil management practices.

With this study, we sought to answer the following questions: How has rainfall and temperature in West Pokot changed from 1980-2011? What LULC changes can be observed in the study area between 1984-2010? What is the phenology of agricultural vegetation in West Pokot County? Do households associate food shortage with climate change and variability? The study provides a comprehensive knowledge base in use of satellite sensor-based maps and statistics that can be used to develop strategies for agricultural and agro-pastoral livelihoods. It helps in the understanding of what locationspecific policies and strategies can be developed in the area for land use planning, natural resource management, and adaptation in the face of climate change. This will offer the West Pokot people a more sustainable and desirable pathway to food security.

\section{Data and Methods}

\subsection{Site Selection}

The study sites were selected to reflect the land classification typology used in West Pokot. The resident Pokot ethnic group themselves utilize and classify their land on the basis of altitude, rainfall, and agricultural potential. The study used this typology to identify three zones of differing agroecological potential (Table 1), which guided selection of three sites (at the division level) within the County (Figure 1). Kapenguria division was chosen to represent the highland zone (known as "masop"), which receives the highest amount of annual precipitation. Medium potential areas ("kamas") were defined as those adjacent to the highlands and were represented by Chepareria division. Most of the areas in Pokot South sub county are in this category. Finally, low potential, mostly arid areas ("tow") far away from the highlands were represented by Kacheliba division. Most of the areas in North Pokot sub-county belong to this category. Table 1 summarizes the study area description and Figure 1 depicts the study sites.

Table 1. Study area description.

\begin{tabular}{lccccc}
\hline $\begin{array}{l}\text { Study } \\
\text { Areas }\end{array}$ & Area (Square kms) & $\begin{array}{c}\text { Agricultural } \\
\text { Potential }\end{array}$ & $\begin{array}{c}\text { Pokot Land } \\
\text { Classification Type }\end{array}$ & $\begin{array}{c}\text { Average Annual } \\
\text { Rainfall (mm) }\end{array}$ & $\begin{array}{c}\text { Average Annual } \\
\text { Temperature }\left({ }^{\circ} \mathbf{C}\right)\end{array}$ \\
\hline Kapenguria & 335.6 & Highland & Masop & 1600 & $<21$ \\
Chepareria & 495 & Midland & Kamas & 600 & 24 \\
Kacheliba & 925.4 & Lowland & Tow & $300-400$ & 28 \\
\hline
\end{tabular}

At the time of the study, Counties had replaced Districts as the largest subnational administrative unit in Kenya, under the 2010 Constitution. Sampling however relied on the pre-2010 administrative units (divisions, locations, sub-locations, and villages), since documentation had yet to be updated at the local level. Sources: [44-46] 


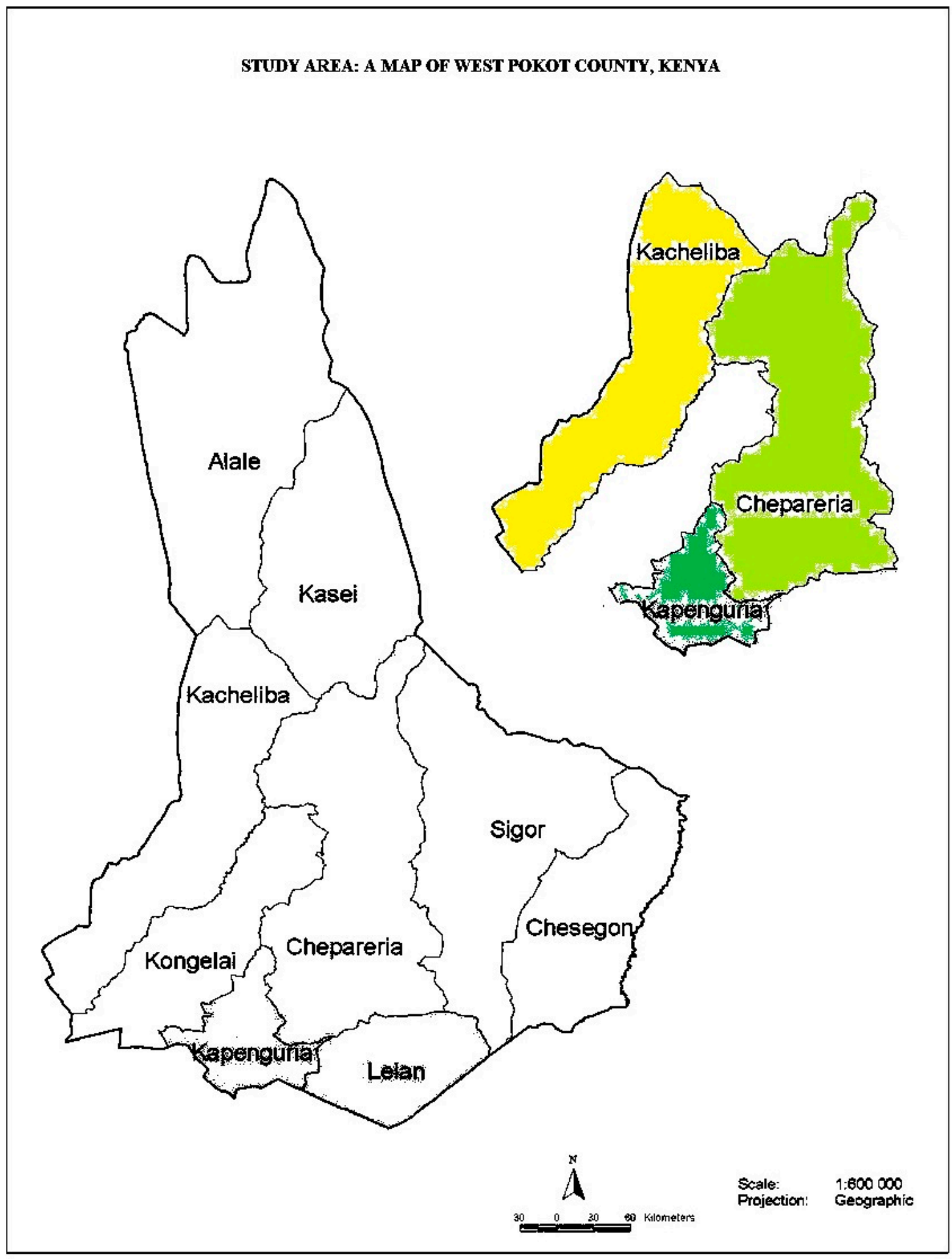

Figure 1. Study sites (redrawn from FAO 2006).

\subsection{Sample Size and Sampling Procedure}

The target population was comprised of households from the three selected divisions (Kapenguria, Chepareria and Kacheliba) of West Pokot County. According to KNBS (2010), West Pokot had a population of 512,690 people and 93,777 households. A sample of 124 households was selected to form the study population using Nasuirma Model formula expressed as follows:

$$
n=\left\{\mathrm{NC}_{\mathrm{v}}{ }^{2}\right\} /\left\{\mathrm{C}_{\mathrm{v}}{ }^{2}+(\mathrm{N}-1) \epsilon^{2}\right\}
$$


where:

$n$-the sample size

$\mathrm{N}$-the target population $(93,777)$

$\mathrm{C}_{\mathrm{V}}$-the coefficient of variation (0.5)

$\epsilon$-the tolerance of desired level of confidence at 95\% level (0.05)

$\left(93,777 \times 0.5^{2}\right) /\left(0.5^{2}+(93,777-1) 0.05^{2}\right)=23,444 / 234.69=100$ respondents

The sample size is often increased by $30 \%$ to compensate for nonresponse [47].

A multistage random sampling was adopted to select participating villages and households for interviews. Kapenguria, Chepareria and Kacheliba divisions were purposively sampled based on food security potential, geographical location, and vulnerability to climatic change and variability. The locations within the three divisions were listed and categorized on the basis of the land use system activities, accessibility, and the extent to which they were perceived to be prone to climate variability and change. Twenty (20) locations from the divisions were randomly selected and respective sub locations and villages were listed along each location. The participating villages were randomly selected and the number of households for the study was obtained. The questionnaires were administered in the three divisions proportional to their share of the total population, whereby 36 respondents from Chepareria, 56 from Kapenguria and 32 respondents from Kacheliba were randomly selected for interviews. The age of the respondents varied from 20 to 80 years and the majority $(51 \%)$ had primary education, with $13 \%$ having no formal education. In addition to the random sampling of rural respondents, purposive sampling was used to select 20 key informants from relevant institutions, including Water and Resource Management Authority, Ministry of Agriculture, Kerio Valley Development Authority and community leaders. The interviews followed a semi structured format, with an in-depth focus in regard to the area of expertise of the informant.

\subsection{Data Acquisition}

The survey was conducted in Jan-March 2013, before the long rains season and used both structured and semi structured questionnaires to elicit information for ground truthing, verification, providing basic information and for the study of perceptions. As noted above, the multistage sampling technique selected 124 household respondents, while purposive sampling identified 20 key informants. Data on rainfall and temperature for West Pokot County was obtained from the Kenya Meteorological Department.

Satellite imagery with $30 \mathrm{~m}$ spatial resolution from Landsat 5 and Landsat 7 was used to analyze LULC changes in West Pokot County. The spatial resolution of Landsat imagery and its multispectral characteristics make it a suitable source of data for environmental and climate studies since various band combinations provide information on the land surface and its properties. SPOT 5 multispectral data sets for the years 1984, 1990, 2000 and 2010 were used for NDVI analysis.

\subsection{Estimation Strategy}

Logistic regression was applied to test the hypothesis that the probability of taking measures to reduce exposure to climate change was related to several predictor variables [48]. Our binary regression equation was of the form:

$$
\operatorname{logit}(Y)=\beta_{0}+\beta_{1} X_{1}+\beta_{2} X_{2}+\ldots+\beta_{n} X_{n}+\varepsilon
$$

Stepwise regression began with 71 possible predictor variables for the dependent variable: "Do you take any measures (in previous and current year) to reduce your exposure to the impacts of climate change on food security risk?" The first reduced model had 18 predictor variables. We conducted a second stepwise regression to get a second reduced model, considering that we only had 124 observations and 18 was a case overfitting. 


\subsection{Image Processing}

For each of the four sets of geo-referenced Landsat data, band combinations generated color composites to allow for interpretation. Layer stacking was done in ERDAS Imagine $15^{\circledR}$ software [49], using the relevant bands (i.e., excluding the Coastal/Aerosol, Panchromatic, Cirrus, and Thermal Infrared bands). Multi-band (multispectral) images covering the entire county were obtained, using bands 2, 3, 4, 5, and 7 (Landsat 5), and bands 1, 2, 3, 4,5 , and 7 for the more recent Landsat 7 images.

The bands help with vegetation enhancement and color contrast. The Normalized Difference Vegetation Index (NDVI) was extracted for each year of study and maps of NDVI were generated. Multispectral vegetation indices were represented by the algebraic combination of remotely sensed spectral bands that indicated the phenology of the vegetation cover. For the state of the crops, the different sensitivity of the mentioned electromagnetic spectra was used to estimate the productivity of the study area. Software used included: ERDAS Imagine $2015^{\circledR}$ [49] to perform the image processing and enhancement, and analyze multispectral image data by means of qualitative and quantitative approaches, Arc GIS $\left({ }^{\mathrm{TM}}\right)$ Version 10.5 [50] for developing maps, and ERDAS Imagine MosaicPro tool for the mosaicking.

\subsection{Data Analysis}

Image classification was examined using visual analysis, classification accuracy, band correlation, and decision boundary. The study considered the requirements set out in the 2006 Intergovernmental Panel on Climate Change (IPCC) [51] guidelines, which define the seven broad land use classes that countries are required to report on under the United Nations Framework Convention on Climate Change (UNFCCC) as: Forestland, Cropland, Open Grassland, Wooded Grassland, Wetland/Open Waters, Settlements, and Other land.

NDVI was used to identify vegetated areas and their associated health. The NDVI anomalies for the years and changes in productivity observed between the subsequent years were also interpreted. The GIS approach provided a spatial framework to support spatiotemporal analysis of Landsat data. The GIS geo-processing tools analyzed information based on vegetation indices and other spatial data.

The variability and time series trend characteristics of rainfall and temperature data were analyzed to inspect the changes in the historical period. Trend detection and analysis were achieved through time series decomposition for both datasets. Multiple logistic regression was used to analyze the adaptive measures taken by respondents in response to climate change. These analyses and graphing were conducted in R software (version 4.1.0) [52] and several of its packages [53-59].

\section{Results}

3.1. Characterizing Annual and Seasonal Rainfall and Temperature from 1980-2011 in West Pokot County

\subsubsection{Rainfall Trend Analysis}

The analysis of monthly rainfall variation for the period between 1980 and 2011 (Figure 2) indicated that rainfall is unpredictable and unreliable, and does not coincide with cropping seasons. As such, it does not provide sufficient water long enough for crop cultivation.

The long-term trend analysis in annual rainfall showed no significant change over time at the County level (Figure 2). Rainfall amounts for West Pokot County fluctuated between a maximum of $1347.9 \mathrm{~mm}$ in 1982 and minimum of $619.4 \mathrm{~mm}$ in the year 2000 with an average annual rainfall of $973.4 \mathrm{~mm}$ (Figure 2). Twelve years (1982, 1988, 1992, 1993, 1994, 1996, 1997, 1999, 2001, 2006, 2007 and 2008) experienced above average precipitation, while seventeen years (1980, 1981, 1983, 1984, 1985, 1986, 1987, 1989, 1990, 1991, 1995, 2000, 2002, 2003, 2004, 2005 and 2009) recorded below average precipitation. 


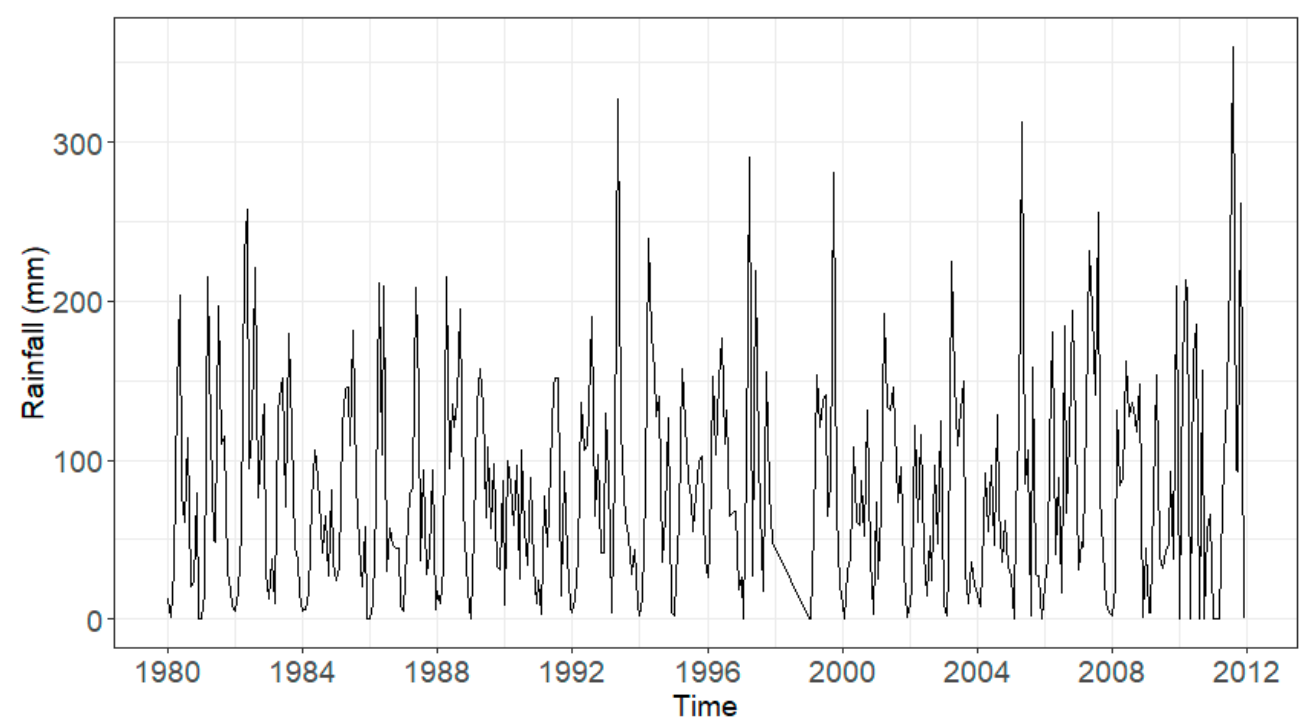

Figure 2. Annual rainfall trend in West Pokot County (1980-2011).

The years that experienced the highest amount of rainfall were $1982(1347.9 \mathrm{~mm})$ followed by $2011(1307.5 \mathrm{~mm}), 2007(1210.7 \mathrm{~mm})$ and $2010(1209.6 \mathrm{~mm})$. The years which recorded the least rainfall amount were $2000(619.4 \mathrm{~mm})$ and the year $1984(631.61 \mathrm{~mm})$. This confirmed reports from the respondents that rainfall had become irregular and unpredictable in terms of amount and distribution affecting crops, such as maize and beans especially during the maturity period. "The year 2000 was a year I cannot forget, I slept hungry most of the days due to crop failure, there were no rains for my crops to grow" a respondent lamented. After the 2000 drought, annual rainfall increased, but with considerable variations further jeopardizing food security.

There was no obvious increasing or decreasing trend in the rainfall data over the study period (Figure 3). The trend component was irregular. Respondents did, however, believe that rainfall amount was diminishing over time, which is not supported by these data. Rainfall levels are not found to significantly decline during the study period, rather a trend in variability in rainfall distribution was. However, the data suggested the presence of seasonality, as expected, where rainfall is heavy or less in specific months of the year. Further examination revealed that rainfall peaked in April, while January recorded the lowest rainfall.

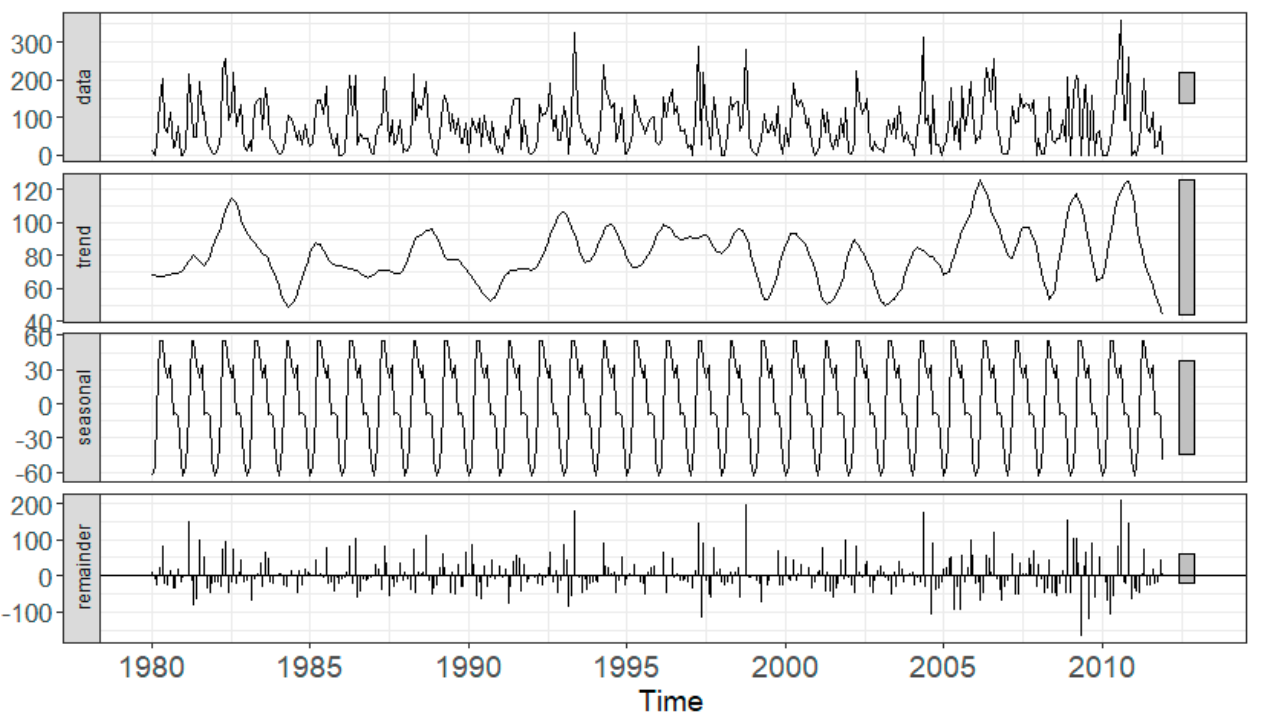

Figure 3. Decomposed time series of rainfall in West Pokot County (1980-2011). 


\subsubsection{Temperature Trend Analysis}

Lowland West Pokot: Average daily temperature per year was calculated for the lowlands (Figure 4).

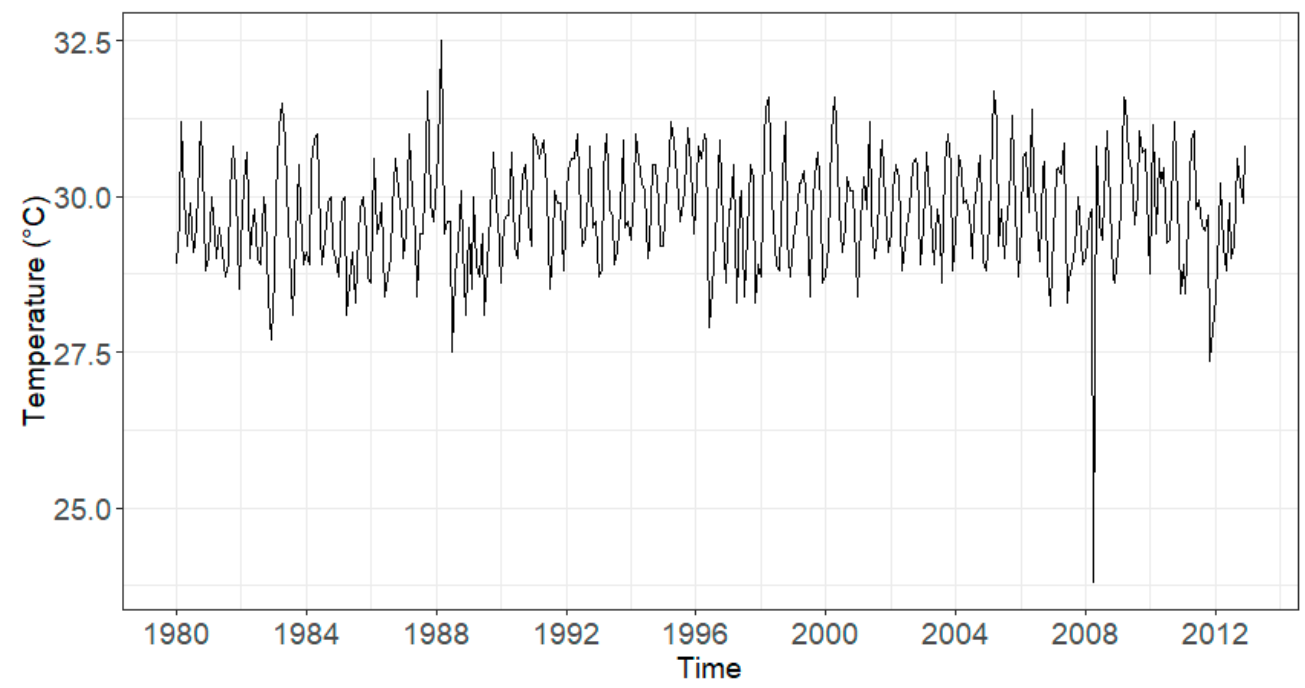

Figure 4. Average daily temperature per month in West Pokot County lowlands (1980-2012).

The average annual temperature for the lowlands over the study period 1980-2012 was $29.74{ }^{\circ} \mathrm{C}$. While annual average results showed that the year 1985 recorded the lowlands lowest annual daily temperature $\left(29.13^{\circ} \mathrm{C}\right)$, monthly averages showed that April 2008 had the lowest average temperature $\left(23.8^{\circ} \mathrm{C}\right)$. We retained the lowest temperature in April 2008 in further analyses, even though it was an outlier. On the other hand, whereas the highest annual average temperature was in $2009\left(30.38^{\circ} \mathrm{C}\right)$, the highest monthly average temperature was in March $1988\left(32.5^{\circ} \mathrm{C}\right)$. The lowlands' mean annual maximum temperature showed warming trends over the study period, with considerable interannual variations, apart from 1997-2006 where the variations were minimal (Figure 5). Overall, there was a significant warming trend in the lowlands' average temperature, which rose $+1.25^{\circ} \mathrm{C}$ over the study period.

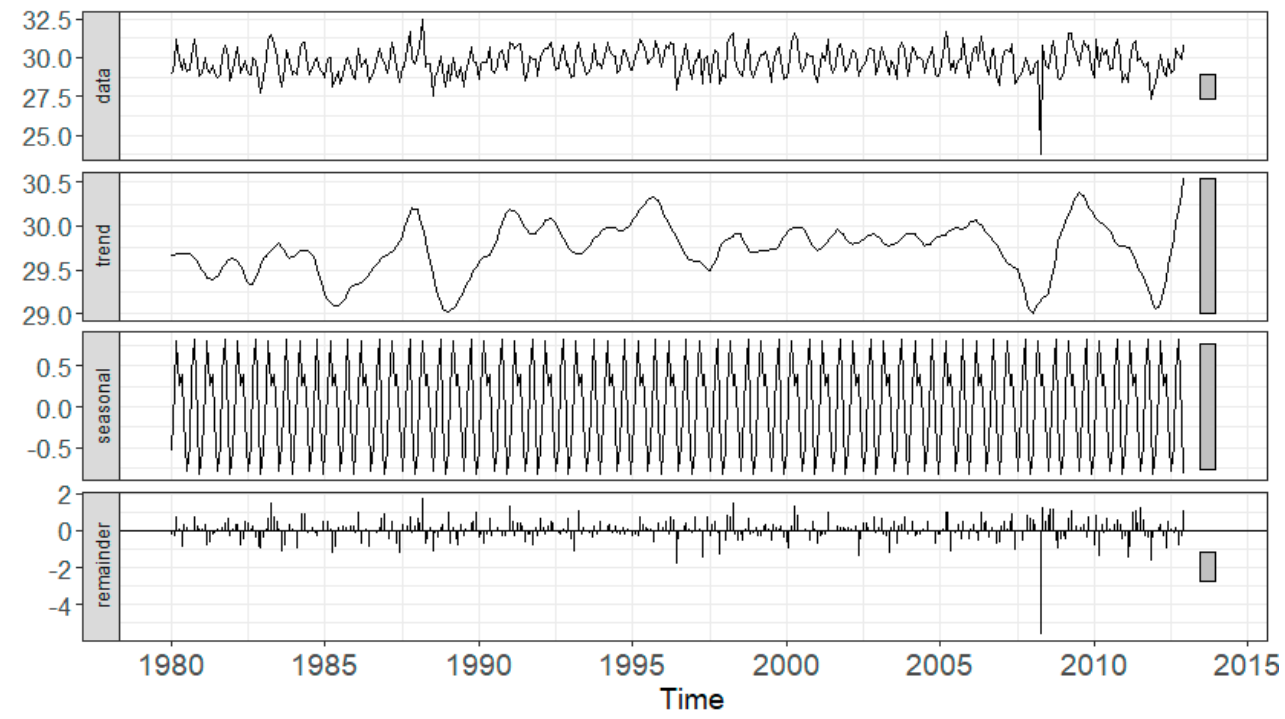

Figure 5. Decomposed time series of average temperature in lowland West Pokot County (1980-2012).

The decomposed time series showed the presence of seasonality in the data of lowland West Pokot. Further examination reveals that average temperatures peaked in March and 
October, while July recorded the lowest temperatures. The trend analysis showed a steady increase between 1997 and 2006, which became irregular irregular in the years following.

Highland West Pokot: Average daily temperature per year was calculated for the highlands (Figure 6).

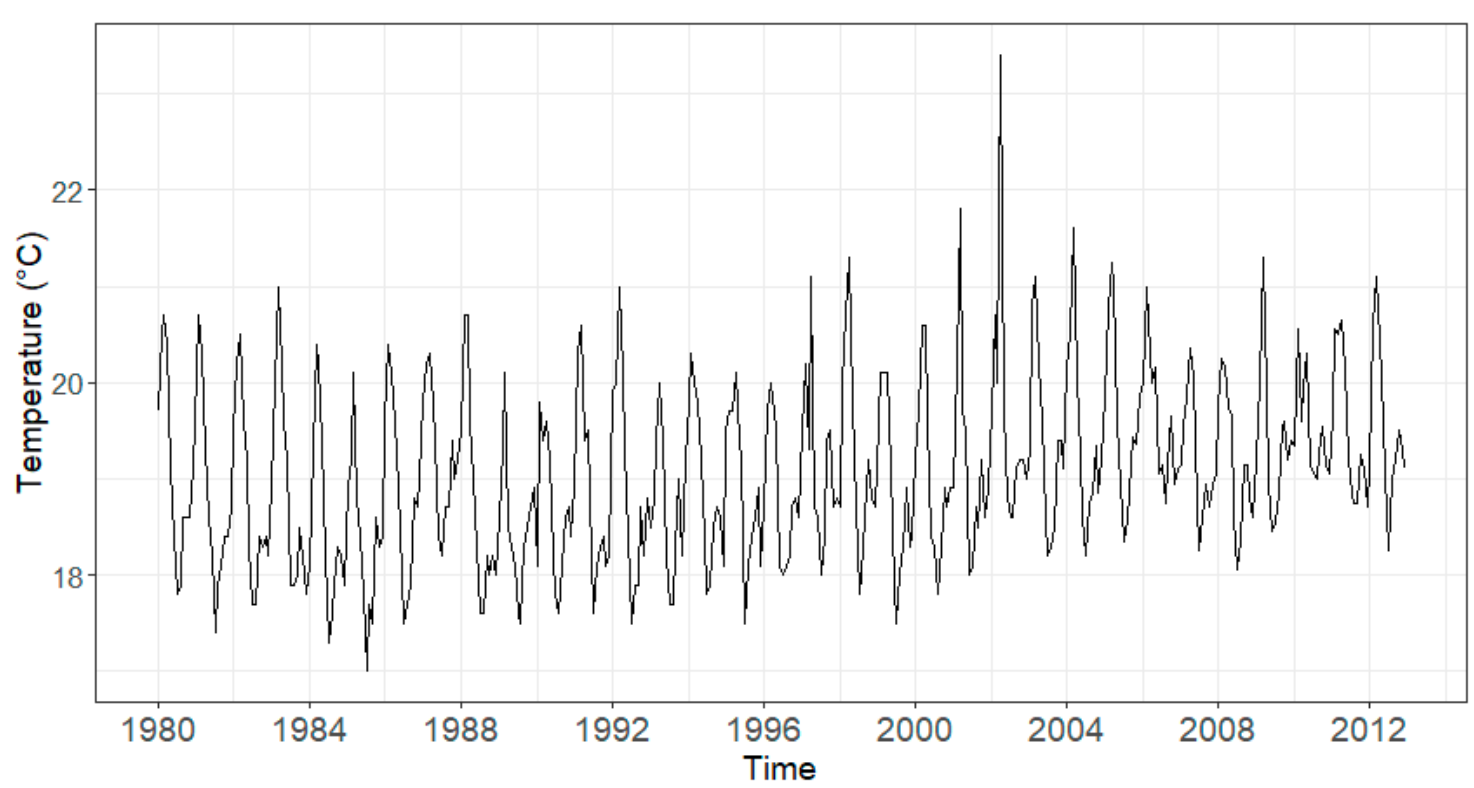

Figure 6. Average daily temperature per month in West Pokot County highlands (1980-2012).

The time series showed an increasing trend in the average temperature by month since 1980. We then decomposed the time series to isolate its components as in Figure 7.

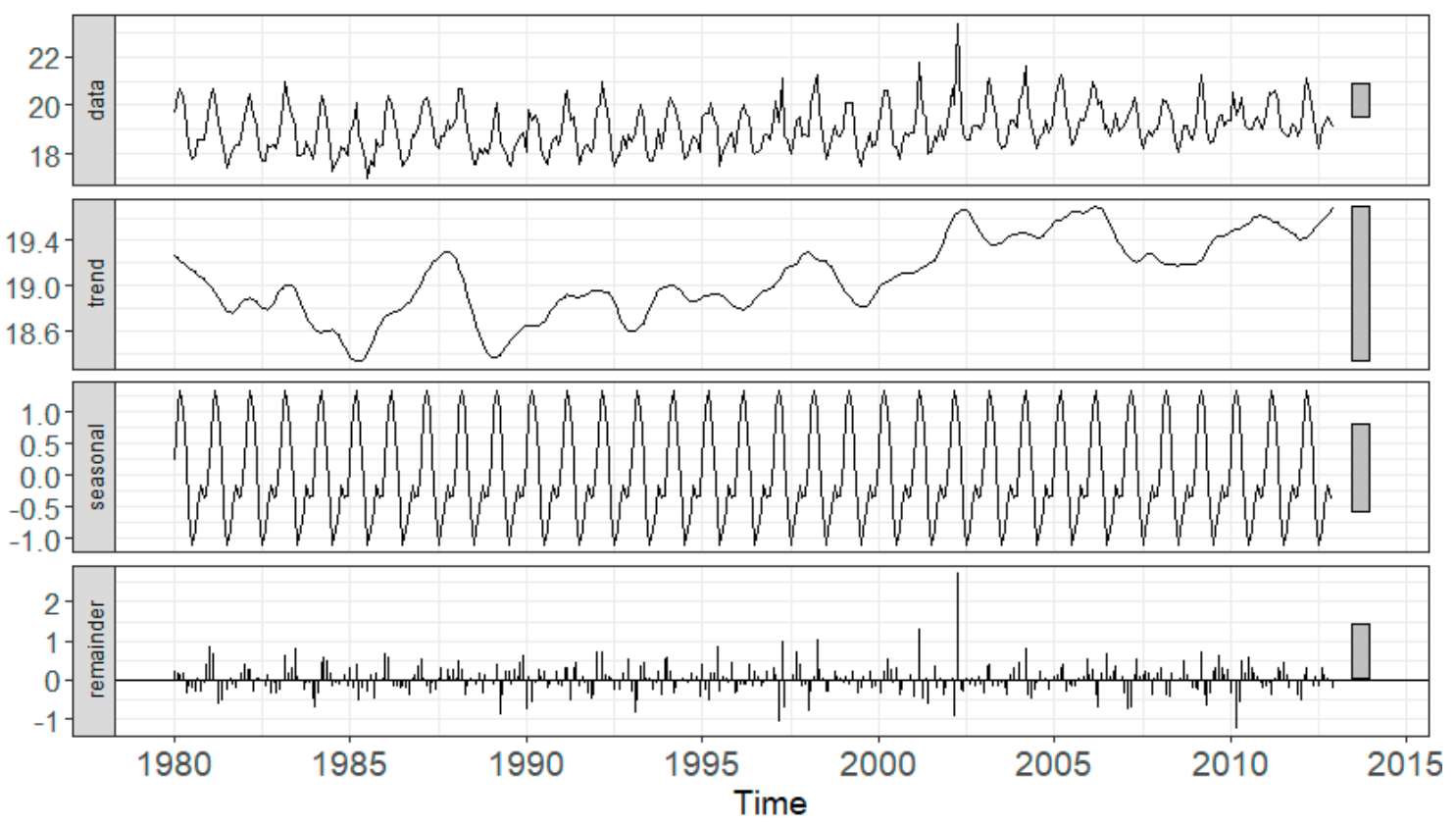

Figure 7. Decomposed time series of average temperature in highland West Pokot County (1980-2012).

The data showed the presence of seasonality in the temperature data. Further examination reveals that average temperatures peaked in March, while July recorded the lowest temperatures. Furthermore, unlike the lowland areas, there was a trend in the time series showing that average temperatures had increased since 1990 in the highland areas. In the highland areas, the year 1985 recorded both the lowest annual daily temperature 
$\left(18.39^{\circ} \mathrm{C}\right)$ and lowest monthly average temperature in July $1985\left(17^{\circ} \mathrm{C}\right)$. On the other hand, whereas the highest annual average was $19.68^{\circ} \mathrm{C}$ in 2005 , the highest ever monthly average temperature was in April 2002 at $23.4{ }^{\circ} \mathrm{C}$.

\subsection{Land Use Land Cover (LULC) Changes}

A total of seven land cover classes were considered namely: Forestland, Cropland, Open Grassland, Wooded Grassland, Wetlands/Open Waters, Settlements, and Other land. Figure 8a-d for 1984, 1990, 2000, and 2010, respectively, show maps of the interpreted images of West Pokot County.

In 1984, wooded grassland was the most dominant LULC in the landscape covering 533461 ha of the total studied area, followed by open grassland (196,775 ha), forestland $(169,452 \mathrm{ha})$, otherlandSs (32,058 ha), open water (1139), cropland (794 ha), and settlements (32 ha) (Table 2). By 2010 there was a substantial increase in croplands (+4176\%). During the same period, other lands (bare lands and rocky areas), open grasslands, and forestland declined by $-71 \%,-49 \%$, and $-38 \%$ respectively. The greatest expansion of cropland occurred between 2000 and 2010 (from 8254 ha to 33,931 ha), whereas forestland recorded its lowest area (86,460 ha) in 2000 followed by a modest increase in the year 2010 . However, area under wooded grassland, open water, and settlement have consistently increased by $+28 \%,+247 \%$, and $+266 \%$ respectively. There was a decline in area coverage for open water in 1990, however it increased considerably in 2000-2010.

Table 2. Changes in area by land use types in West Pokot County (1984-2010).

\begin{tabular}{|c|c|c|c|c|c|}
\hline Landuse/Area in Hectares (Ha) & 1984 & 1990 & 2000 & 2010 & Net Change \\
\hline Cropland & 794 & 4938 & 8254 & 33,931 & $+33,138(+4176 \%)$ \\
\hline Forestland & 169,452 & 122,004 & 86,460 & 104,443 & $-65,010(-38 \%)$ \\
\hline Open Grassland & 196,775 & 123,176 & 110,502 & 99,787 & $-96,988(-49 \%)$ \\
\hline Open Water & 1139 & 498 & 1070 & 3957 & $+2818(+247 \%)$ \\
\hline Otherland & 32,058 & 9910 & 8978 & 9361 & $-22,698(-71 \%)$ \\
\hline Settlements & 39 & 47 & 70 & 142 & $+103(+266 \%)$ \\
\hline Wooded Grassland & 533,461 & 673,114 & 718,359 & 682,734 & $149,274(+28 \%)$ \\
\hline
\end{tabular}

Accuracy assessment of the classification was computed after field verification and validation. It compared the classified image to ground truthed data collected from the field. A set of random points from the ground truth data was created and compared to the classified data in a confusion matrix. Table 3 shows the accuracy assessment results. The overall accuracy of the classification is $74.42 \%$ with a Kappa coefficient of 0.674 . Relative to the size of the region covered by the study, the classification accuracy is relatively good.

Table 3. West Pokot County (2010 landcover map error matrix).

\begin{tabular}{|c|c|c|c|c|c|c|c|c|}
\hline Class EVF & Settlement & Forestland & Cropland & Otherland & Open Grassland & Wetland & Wooded Grassland & Total \\
\hline Settlement & 1 & 0 & 1 & 0 & 0 & 0 & 0 & 2 \\
\hline Forestland & 0 & 8 & 0 & 0 & 0 & 0 & 0 & 8 \\
\hline Cropland & 1 & 0 & 12 & 0 & 3 & 0 & 3 & 19 \\
\hline Otherland & 0 & 1 & 0 & 5 & 0 & 0 & 0 & 6 \\
\hline Open grassland & 0 & 0 & 0 & 0 & 2 & 0 & 0 & 2 \\
\hline Wetland & 0 & 0 & 0 & 0 & 0 & 1 & 0 & 1 \\
\hline Wooded grassland & 0 & 0 & 0 & 0 & 2 & 0 & 3 & 5 \\
\hline Total Sampled Points & 2 & 9 & 13 & 5 & 7 & 1 & 6 & 43 \\
\hline
\end{tabular}




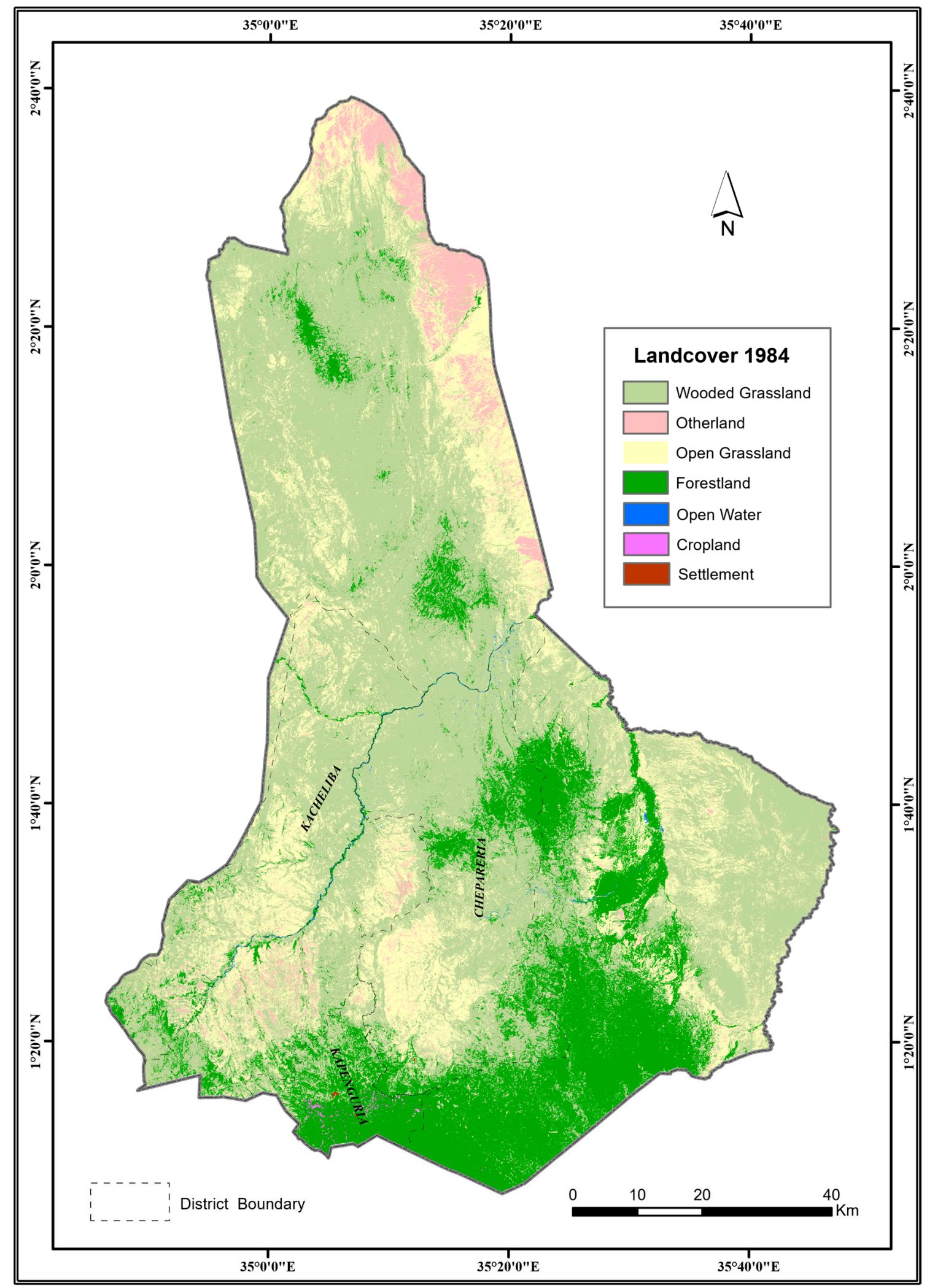

(a)

Figure 8. Cont. 


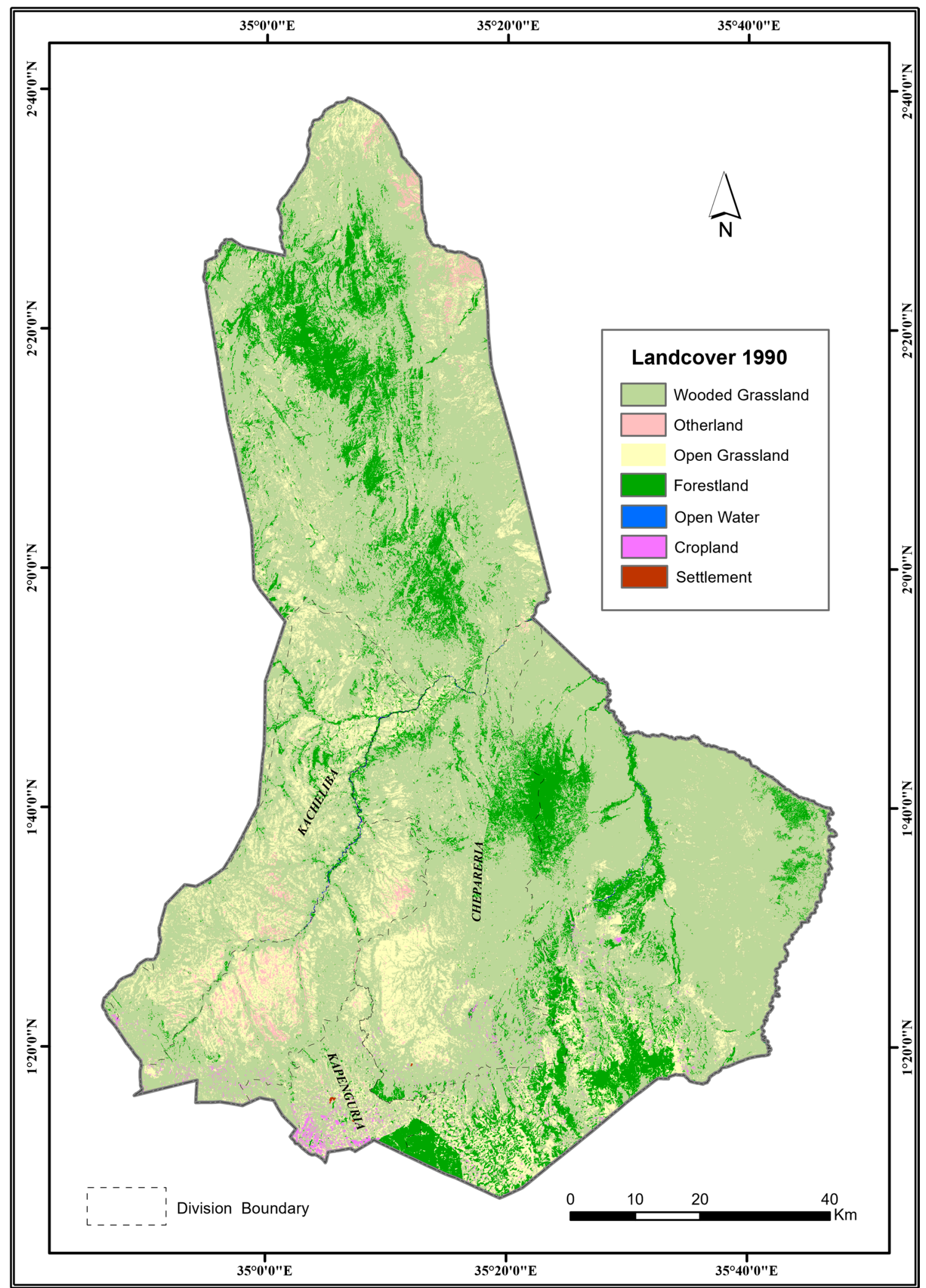

(b)

Figure 8. Cont. 


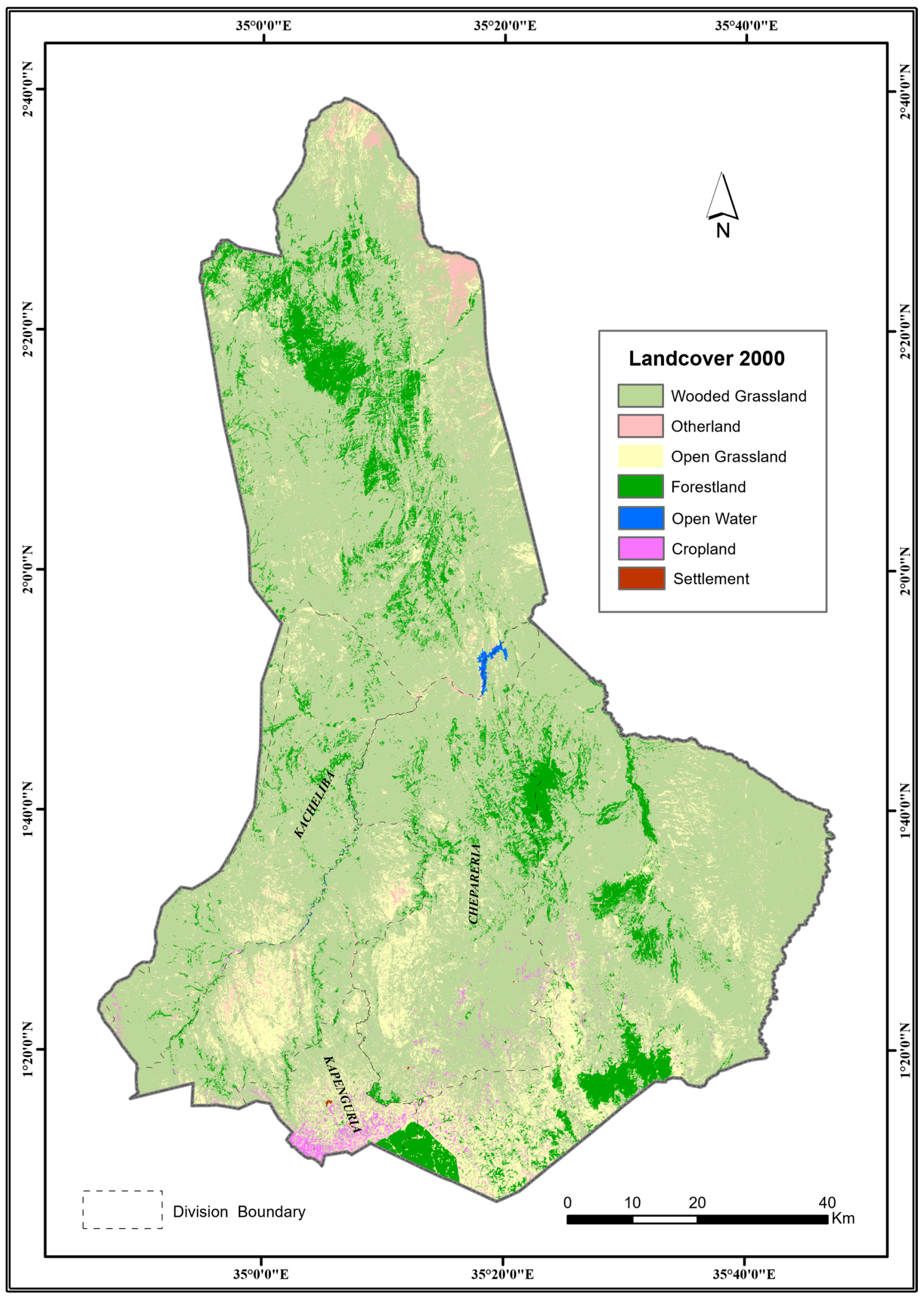

(c)

Figure 8. Cont. 


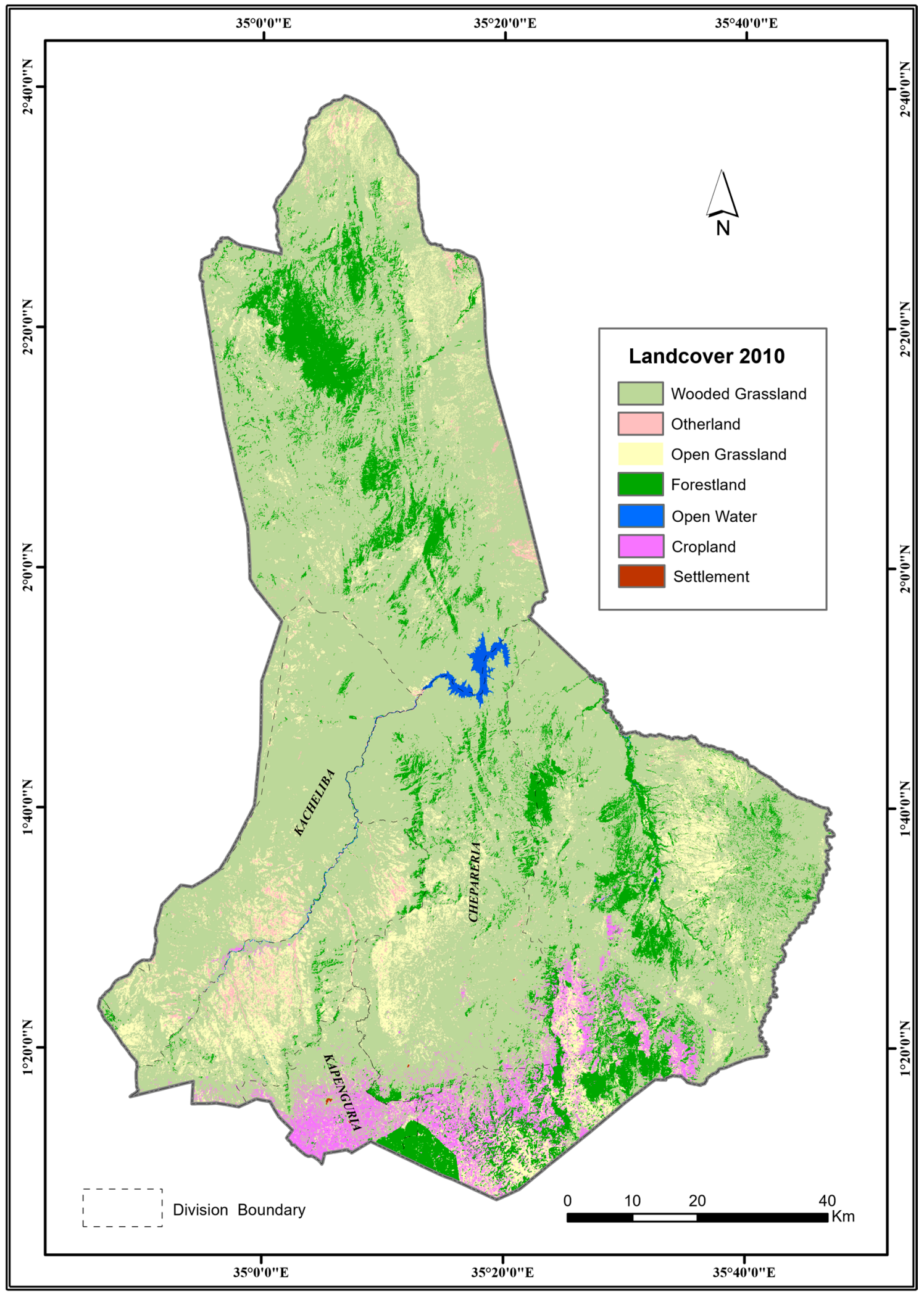

(d)

Figure 8. (a) Land use land cover, 1984; (b) Land use land cover, 1990; (c) Land use land cover, 2000; (d) Land use land cover, 2010. 


\subsection{The Phenology of Agricultural Vegetation in West Pokot County}

The inter annual variation in NDVI was assessed for West Pokot County for the period from 1984 to 2010 and the vegetation production represented by NDVI images, Figure 9a-d.

There was a high variability of vegetation cover in West Pokot. The normal vegetation pattern has been disturbed and dominated by significantly greater variation from one year to another. Normal vegetation meant healthy vegetation while poor meant moisturestressed vegetation.

The county was dominated with healthy and some patches of moisture-stressed vegetation in 1984 (Figure 9a), even though the amount of rainfall it recorded was low $(631.6 \mathrm{~mm})$. This followed the above average rainfall amount $(1347.9 \mathrm{~mm})$ experienced in 1982 which had enhanced adequate soil moisture that supported vegetation growth in the year 1982 followed by slightly below average rains $(956.8 \mathrm{~mm})$ in 1983 which sustained the growth.

The year 1990 showed a poor and very poor state of vegetation especially in some parts of the midlands and lowlands (Figure $9 \mathrm{~b}$ ). This follows a continued stretch of below average rains (1984, 1985, 1986, 1987 and 1989). Even though 1988 recorded above average rains $(1069 \mathrm{~mm})$, the county was recovering from frequent dry spells and still suffering from moisture stress, hence, negligible impacts on vegetation. This is especially evident in the lowlands, where poor vegetation dominated in 1990. Chepareria was the most affected part of the midlands. The highlands, especially the Kapenguria area, also recorded poor and only a few patches of good vegetation. Only along the River Suam was vegetation in a normal state.

The green cover improved for the year 2010 (Figure 9d) following the high rains (1209.6 $\mathrm{mm}$ ) recorded that year, and good rains experienced in the previous years (2005-2008) meaning the vegetation was healthy and received enough rain. The highlands indicated very good vegetation and the midlands were dominated by normal vegetation. Some parts of the lowlands however recorded poor vegetation. 


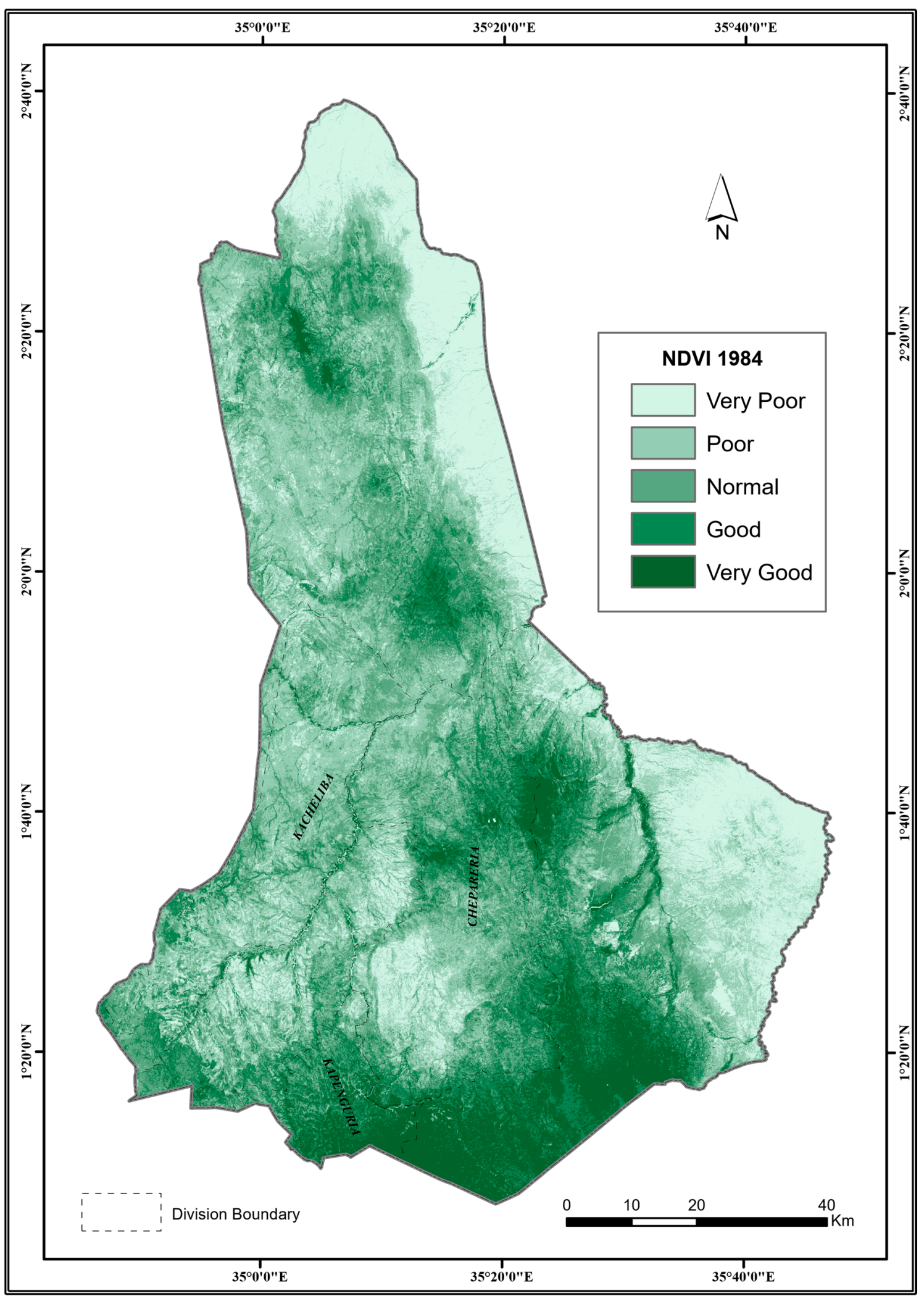

(a)

Figure 9. Cont. 


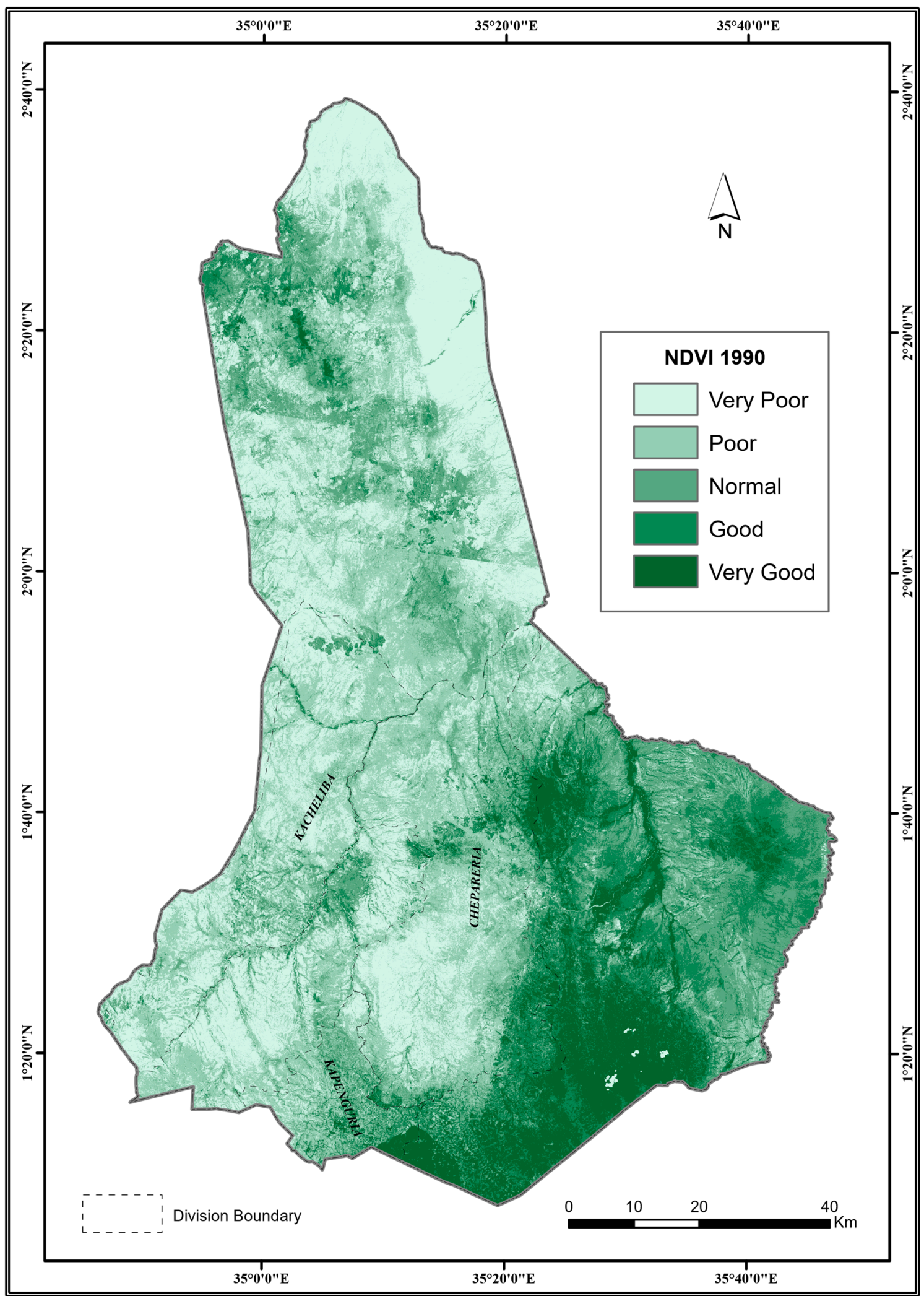

(b)

Figure 9. Cont. 


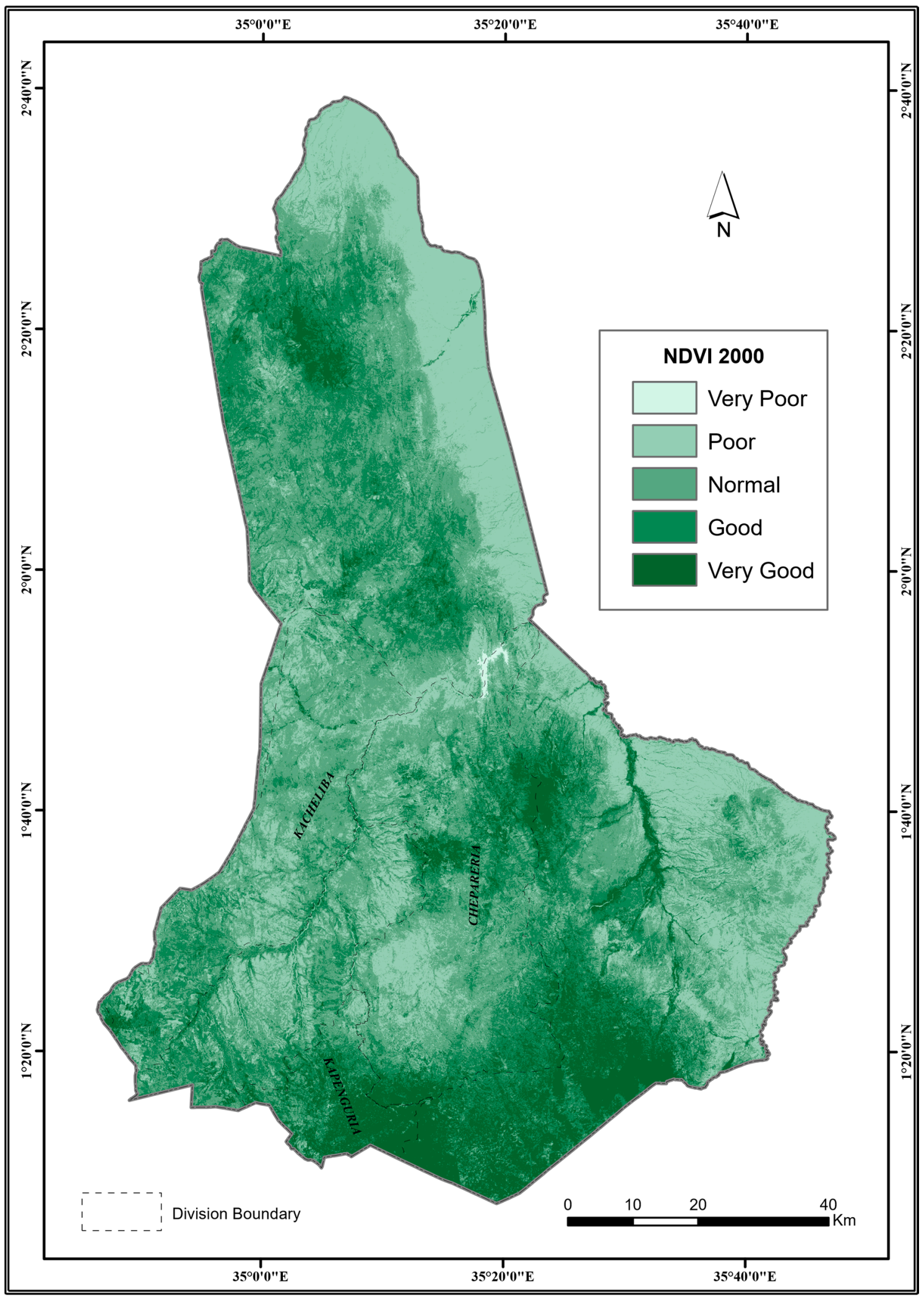

(c)

Figure 9. Cont. 


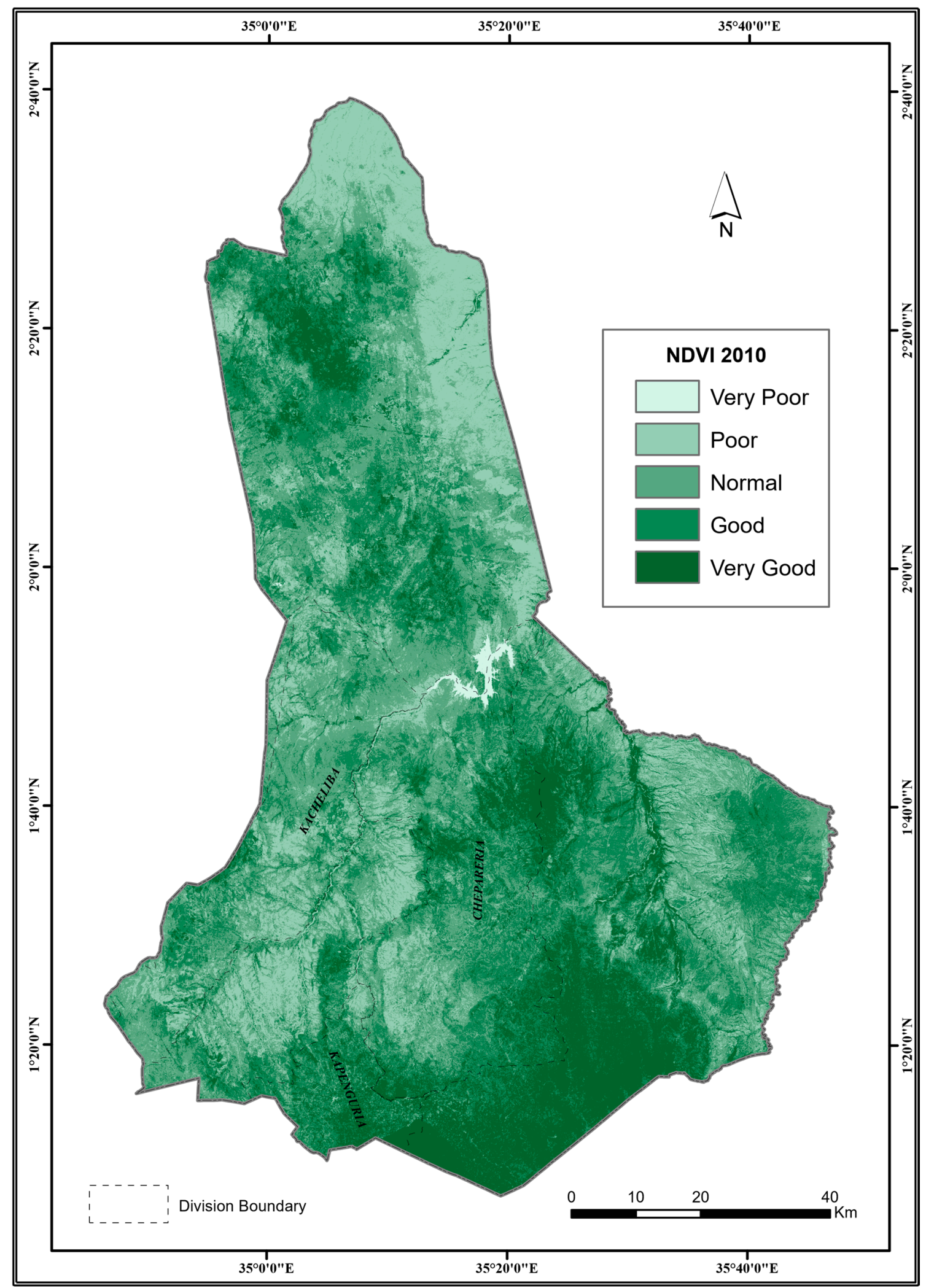

(d)

Figure 9. (a) Vegetation production, 1984; (b) Vegetation production, 1990; (c) Vegetation production, 2000; (d) Vegetation production, 2010. 
Analysis of NDVI Anomalies in West Pokot County

The NDVI time series in West Pokot County show very low values from January to February. The NDVI values then increase and peak in June before it starts decreasing until July (Figure 10). From July to September, the NDVI values show a stable trend, after which the values decrease from September to November. This NDVI pattern shows close correspondence with the monthly rainfall anomalies in the area. However, in the analysis of the relationship of rainfall and NDVI value when $p<0.05$ is significant, results show that changes in NDVI value versus rainfall is not significant $p=0.219$, as supported by the lag in one month for NDVI to reach its peak.

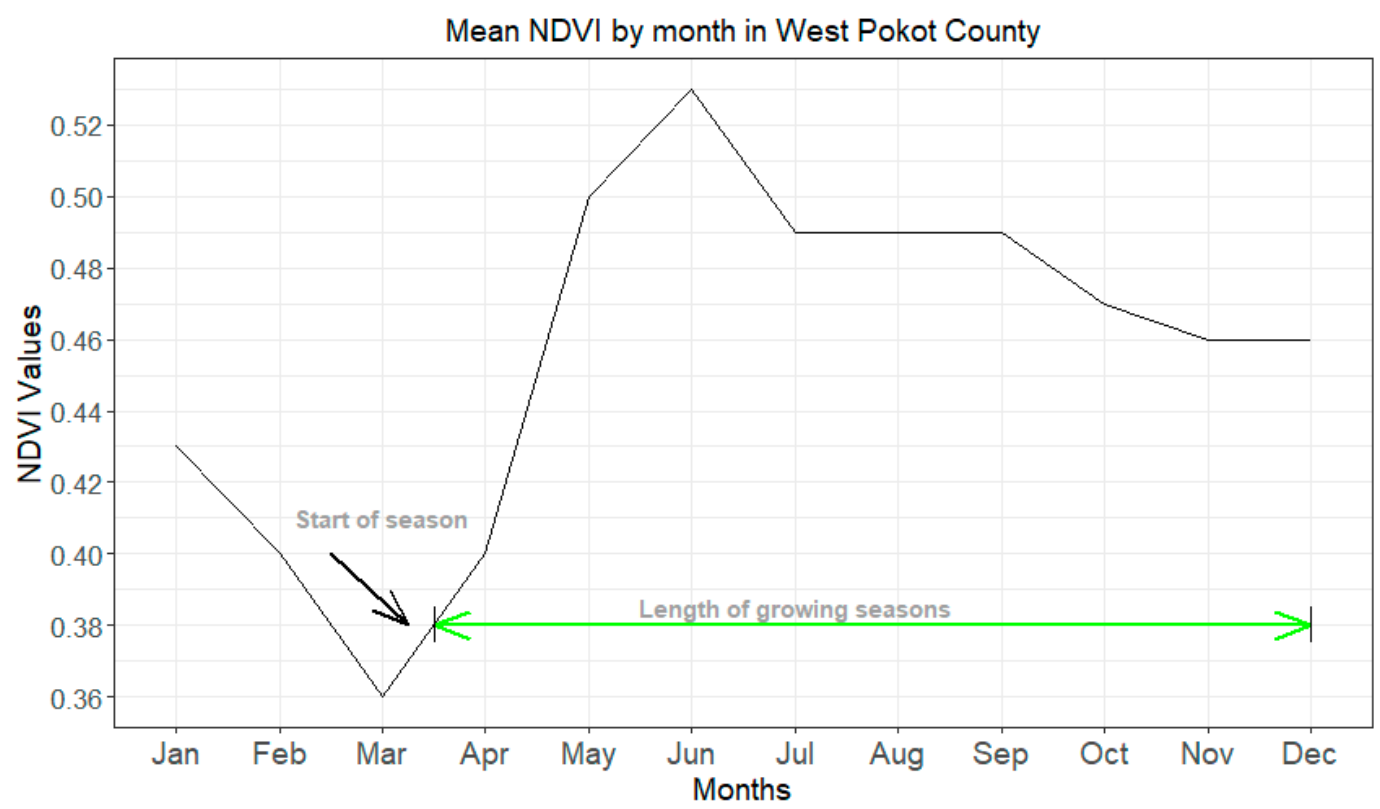

Figure 10. Mean NDVI values trend by month in West Pokot.

3.4. Perception of the Relationship between Food Insecurity and Climate Change and Variability in the Area

3.4.1. Effect of Climate Variability on Crop Production

Maize and beans were the main crops, while vegetables (such as cabbages and kales), potatoes, bananas and groundnuts were also grown. Respondents reported a high level of food insecurity. A majority (74\%) stated they did not have enough food to sustain them previously and at the time of their interviews, and $60 \%$ of the respondents projected that food would not be enough in the following year. The respondents reported changed rainfall and temperature variables when discussing food security (Table 4). More respondents in the lower potential lowlands (Kacheliba) reported that they were "greatly affected" by climate changes $(75 \%)$ while only $14 \%$ of the respondents in the high potential highlands (Kapenguria) said food production was "greatly affected". Barely any respondents (3\%) noted no effect of climate change, but Kapenguria respondents were the most likely (84\%) to report that food production was "slightly affected".

Table 4. Extent of climate change effect on food production, as reported in the study areas of West Pokot County $(2017, n=124)$.

\begin{tabular}{ccccc}
\hline \multicolumn{4}{c}{ \% Extent of Climate Change Effect on Food Production } \\
\hline & Kapenguria & Chepareria & Kacheliba & All \% \\
\hline Greatly Affected & 14 & 27 & 75 & 34 \\
Slightly Affected & 84 & 66 & 25 & 63 \\
Did Not Affect & 2 & 7 & 0 & 3 \\
& 100 & 100 & 100 & 100 \\
\hline
\end{tabular}




\subsubsection{Change in Crop Growing Seasons}

In general, more respondents (44\%) reported crop growing seasons were shorter than before, 38\% reported no change, and $6 \%$ indicated that it varied year to year depending on rainfall distribution (Table 5). Important regional variations can be noted though. While highland (Kapenguria) respondents were more likely to report observing "no change" (55\%) than "shorter seasons" (33\%), midland (Chepararia) respondents reported "shorter seasons" $(46 \%)$ more often than "no change" $(39 \%)$. The lowlands were most affected as compared to the other agroecological zones. In Kacheliba, 57\% of respondents reported "shorter seasons" while $25 \%$ said it "varied year to year depending on rainfall distribution". A handful of Kacheliba respondents (3\%) even reported "longer growing seasons", although this was likely due to their reliance on irrigation from the River Suam for their crop production.

Table 5. Reported changes in crop growing seasons in West Pokot County $(2017, n=124)$.

\begin{tabular}{|c|c|c|c|c|}
\hline Temporal Attributes of Growing Season Changes & Kapenguria & Chepareria & Kacheliba & All (\%) \\
\hline Shorter & 33 & 46 & 57 & 44 \\
\hline Stayed the same & 55 & 39 & 9 & 38 \\
\hline Longer & 12 & 15 & 6 & 11 \\
\hline Much shorter & 0 & 0 & 0 & 0 \\
\hline Much longer & 0 & 0 & 3 & 1 \\
\hline Varies depending on rainfall occurrence & 0 & 0 & 25 & 6 \\
\hline
\end{tabular}

\subsubsection{Perceived Changes in Crop Yield over Time}

The majority of respondents (65\%) reported a decline in crop yields (Table 6). Nearly all (97\%) respondents in lowland Kacheliba reported a decline, supported by a majority of midland Chepareria respondents (61\%), and almost half (49\%) of Kapenguria respondents. In the highland and midland, respondents ( $24 \%$ and $27 \%$, respectively) reported steady yields, and $16 \%$ of the respondents said crop yields had increased. This could be attributed to those who practiced irrigation in the highlands and some parts of the midlands as an adaptation measure (only $3 \%$ in the lowlands reported an increase).

Table 6. Reported changes in crop yield over time in West Pokot County $(2017, n=124)$.

\begin{tabular}{ccccc}
\hline \multicolumn{5}{c}{ Agro-ecological zone } \\
\hline Kapenguria & Chepareria & Kacheliba & All \% \\
\hline Declined & 49 & 61 & 97 & 65 \\
Steady & 24 & 27 & 0 & 19 \\
Increased & 27 & 12 & 3 & 16 \\
\hline
\end{tabular}

\subsubsection{Weather Forecast Information Access by the Respondents}

Respondents reported they had little access to weather forecasts. The most commonly reported source of weather information was from the radio ( $64 \%$ of respondents), ranging from $80 \%$ of Kapenguria's respondents to $44 \%$ in Kacheliba. Traditional forecasters were the next most often reported source (26\%), especially by respondents in Chepareria $(34 \%)$ and Kacheliba (28\%). Other sources of weather information mentioned included TVs, predictions given by local elders, and government agents. Most respondents indicated that they had more confidence in traditional forecasters than the radio ( $14 \%$ of respondents in Kapenguria reported combining radio with traditional forecasts). Even though it was the region with the most problematic agro-ecology, respondents in Kacheliba were the most likely (22\%) to report having no access to forecast information, in comparison to Kapenguria (16\%) or Chepareria (10\%). Overall, respondents reported a desire for forecasts about whether the amount of rainfall would be above average, normal, or below average, distribution of rainfall during the season, and when rains were expected to fall in the area. 
3.4.5. Measures Taken to Reduce Exposure to the Impacts of Climate Change

The results of the first reduced model are shown in Table 7 and the second reduced model in Table 8.

Table 7. Logistic Regression Analysis of 124 respondents on measures to reduce exposure to climate change on food security (Model 1).

\begin{tabular}{|c|c|c|c|}
\hline \multicolumn{4}{|c|}{ Dependent Variable: Do You Take Any Measures to Reduce Your Exposure to The Impacts of Climate Change on Food Security Risk? } \\
\hline & Coefficient & Std. Error & Odds (Exponential of Coefficient) \\
\hline Intercept & -22.655 & 1311.778 & $\sim 0.00$ \\
\hline Gender of respondent (Male) & $1.863 * * *$ & 0.591 & 6.443 \\
\hline Acreage under crop farming & $-0.350 * *$ & 0.160 & 0.705 \\
\hline $\begin{array}{l}\text { How has your production been over } \\
\text { time since last year up to now? } \\
\text { (Remained the same) }\end{array}$ & $-1.345^{* *}$ & 0.640 & 0.260 \\
\hline $\begin{array}{l}\text { How has your production been over } \\
\text { time since last year up to now? } \\
\text { (Increased) }\end{array}$ & 0.736 & 0.804 & 2.087 \\
\hline $\begin{array}{l}\text { Do you have enough food for your } \\
\text { household currently? (Yes) }\end{array}$ & $1.205 *$ & 0.696 & 3.338 \\
\hline $\begin{array}{l}\text { Has there been any project targeted at } \\
\text { improving the food insecurity } \\
\text { condition in your area? (Yes) }\end{array}$ & $-1.680 * * *$ & 0.648 & 0.186 \\
\hline $\begin{array}{l}\text { How would you rate the quantity of } \\
\text { food in your household? (Bad) }\end{array}$ & 1.287 & 0.967 & 3.620 \\
\hline $\begin{array}{l}\text { How would you rate the quantity of } \\
\text { food in your household? (Good) }\end{array}$ & $2.199 * *$ & 1.030 & 9.016 \\
\hline $\begin{array}{l}\text { How would you rate the quantity of } \\
\text { food in your household? (Very good) }\end{array}$ & $5.430 *$ & 2.851 & 228.223 \\
\hline $\begin{array}{l}\text { Do you depend on relief food when } \\
\text { size of land under crop production } \\
\text { reduces (Yes) }\end{array}$ & $2.313^{* * *}$ & 0.663 & 10.107 \\
\hline $\begin{array}{c}\text { How has climate change affected food } \\
\text { production for your household since } \\
\text { last year up to } \\
\text { now? (Greatly affected) }\end{array}$ & 21.466 & 1311.778 & $2,102,432,864.730$ \\
\hline $\begin{array}{c}\text { How has climate change affected food } \\
\text { production for your household since } \\
\text { last year up to } \\
\text { now? (Slightly affected) }\end{array}$ & 20.910 & 1311.777 & $1,205,886,624.298$ \\
\hline $\begin{array}{l}\text { Observations } \\
\text { Log Likelihood } \\
\text { Akaike Inf. Crit. }\end{array}$ & & & $\begin{array}{c}124 \\
-56.623 \\
139.245\end{array}$ \\
\hline
\end{tabular}


Table 8. Logistic Regression Analysis of 124 respondents on measures to reduce exposure to climate change on food security (Model 2).

\begin{tabular}{|c|c|c|c|}
\hline & Coefficient & Std. Error & Odds (Exponential of Coefficient) \\
\hline Intercept & -0.373 & 0.626 & 0.688 \\
\hline Gender of respondent (Male) & $1.588^{* * *}$ & 0.591 & 4.892 \\
\hline Acreage under crop farming & -0.163 & 0.125 & 0.850 \\
\hline $\begin{array}{l}\text { How has your production been over time since } \\
\text { last year up to now? (Remained the same) }\end{array}$ & $-1.157^{* *}$ & 0.545 & 0.314 \\
\hline $\begin{array}{l}\text { How has your production been over time since } \\
\text { last year up to now? (Increased) }\end{array}$ & 0.479 & 0.700 & 1.615 \\
\hline $\begin{array}{c}\text { Do you have enough food for your household } \\
\text { currently? (Yes) }\end{array}$ & $1.493^{* * *}$ & 0.563 & 4.449 \\
\hline $\begin{array}{c}\text { Has there been any project targeted at } \\
\text { improving the food insecurity condition in } \\
\text { your area? (Yes) }\end{array}$ & $-1.226^{* *}$ & 0.531 & 0.293 \\
\hline $\begin{array}{l}\text { Do you depend on relief food when size of } \\
\text { land under crop production reduces (Yes) }\end{array}$ & $1.903^{* * *}$ & 0.551 & 6.708 \\
\hline $\begin{array}{l}\text { Observations } \\
\text { Log Likelihood } \\
\text { Akaike Inf. Crit. }\end{array}$ & & $\begin{array}{r}1 \\
-6 \\
14\end{array}$ & \\
\hline
\end{tabular}

Note: ${ }^{* *} p<0.05 ;{ }^{* * *} p<0.01$.

To achieve a final parsimonious model, we selected all the predictor variables that were significant in the second reduced model as shown in Table 8.

The significant predictor variables of the final model were gender $(1=$ male, $0=$ female), having enough food for household $(1=$ yes, $0=$ no), state of production since the previous year (remained the same, decreased, or increased), any project targeted at improving food security $(1=$ yes, $0=$ no), and being dependent on relief food when size of land under crop reduces $(1=$ yes, $0=$ no). The results showed that:

Predicted logit of (Measures taken to reduce exposure to the impacts of climate change on food security risk) $=$ $-0.373+1.588 *$ Gender $+(-0.163) *$ Acreage under crop $+(-1.157)$

* How has been your production over time sin ce last year up to now? [Remained the same] +0.479

* How has been your production over time sin ce last year up to now? [Increased] +1.493

* Has enough food $+(-1.226) *$ Food sec urity project +1.903

* Dependonrelieffood

According to the model, the odds of a male respondent taking measures to reduce exposure to climate change were $4.89\left(=e^{1.588}\right)$ times greater than the odds for a female respondent. Given the same gender, the odds of a respondent with enough food taking these measures were $4.45\left(=e^{1.493}\right)$ times greater than a respondent reporting inadequate food. Holding all other variables constant, a respondent with similar production last year had odds of 0.31 to take up measures, relative to respondents with decreased production. Those with decreased production were more likely to take up these measures to reduce their exposure. Furthermore, respondents who reported a food security related project in the area had odds of 0.29 for taking up measures to reduce exposure to climate change on food security risk. In conclusion, given the same gender and food adequacy state and all other variables holding constant, the odds of a respondent that was dependent on relief food when size of land under crop reduces were $6.71\left(=e^{1.903}\right)$ times greater than a respondent who had never received relief food. The model AIC was 149.64. 


\section{Discussion}

4.1. Characterizing Annual and Seasonal Rainfall and Temperature from 1980-2011 in West Pokot County

The increase in mean temperature confirms climate change and variability in West Pokot County in excess of the global mean temperature increase $\left(+0.85^{\circ} \mathrm{C}\right.$ between 1980 and 2012) shown by IPCC [20]. The increase in temperature over time in both the highlands and lowlands of West Pokot agrees with Naanyu [22], who anticipated warmer temperatures in Kenya. Collins [60] indicated that rapid warming from 1979 onwards was witnessed in Kenya. Ogutu et al. [61] focusing on 21 arid and semi-arid (ASALs) counties of Kenya indicated warming of these counties. In Africa, Issahaku et al. [62] and Safari [63] recorded similar results of significant warming temperature trends in Ghana and Rwanda. In addition, King'uyu et al. [64] found evidence of significant warming in the East Africa region.

Kurukulasuriya [65] warned that high temperatures are harmful to productivity, confirming that global warming is likely to have devastating effects on agriculture unless farmers take adaptation measures to counter the impact of climate change. Rising temperature would expose millions of people to drought and hunger. Warming leads to higher rates of evaporation [66], puts additional stresses on water resources [67], and causes sterility during the reproductive period [68]. These effects on fertilization and grain formation resultin diminished yields [69] and escalated livelihood vulnerability.

With rainfall being a prime input and requirement for plant life in rain-fed agriculture, the occurrence of dry spells has particular relevance to rain-fed agricultural productivity [70]. There is a highly variable trend in rainfall in West Pokot, with the number of years recording rainfall of below-average outnumbering those of above. Akponikpe et al. [71] also reported similar trends of high variability (a coefficient of variation of 57\%) in temporal annual rainfall in the Sahel region, while Mzezewa et al. [72] reported even higher coefficients of variation for seasonal (315\%) and annual (50-114\%) rainfall at a semiarid site in Limpopo Province, South Africa.

However, several studies show varying results for rainfall trends in Kenya. For example, in the Western part of Kenya, Githui et al. [73] reported increasing amounts of annual rainfall $(+2.4$ to $+23.2 \%)$ from the 1970 s up to 2008 , while in the Eastern part of Kenya, Rao et al. [74] found no discernible increasing or decreasing trend either in annual or seasonal rainfall. However, Watson et al. [75] recognised that rainfall results around the region are not consistent. Christensen et al. [76] found a discrepancy in observed rainfall tendencies from the 4th IPCC assessment, particularly relating to the long rains (June -August) precipitation, noting that there is a substantial spread between the rainfall projections of different models. The IPCC report does acknowledge that the models it used often have difficulty representing the key processes affecting rainfall and its seasonal distribution in Eastern Africa, with typical correlations of less than 0.3 over land surfaces [77]. Lyon and Vigaud [78] on the other hand argued that the models may be accurate but extreme weather events such as El Niño could cloud the overall picture while explaining the 'East African paradox'.

\subsection{Land Use Land Cover (LULC) Changes}

The changes in LULC illustrated both the impacts of irregular rainfall over the period from 1980-2011 and the complex, human responses to this variability. As noted above, low rainfall years in the 1980s and 1990s contributed immensely to reduced green cover, especially around the highland regions. The gradual decrease in rainfall and longer dry spells resulted in expanded cropland area, which was viewed as a quick coping strategy to the reduced yields that followed failed rains. Farmers began opening croplands in the lowlands, especially along River Suam. Although the changes in LULC do not directly imply a degradation of the land, improper handling of land use may lead to a "landslide effect" resulting in new problems [79], including exacerbating land degradation and soil erosion, which might reduce the overall yield of food crops. The slight increase in forest cover in 2010 reflected renewed government efforts in afforestation [23], although trees 
take time to mature. The annual temperature trend with more gradual peaks $(1983,1992$, 1995 and 2009) preceded rainfall seasons. This may be explained by the effect of reduced vegetation cover and the expansion of land uses that expose the land such as croplands and settlements. Fall et al., [80] indicated that climate forcing from LULC dynamics significantly impacts local temperature trends.

However, changes in cropland and forestland can be explained not only by reduced primary productivity but also the pressure that the county's dependence on rain-fed agriculture has put on forest cover, which was overutilised, and converted to agricultural lands, especially around in the highlands [44,81]. This makes agricultural expansion the dominant direct cause of deforestation in the area and agrees with the County Government of West Pokot [82], that encroachment and clearing for cultivation, demand for timber and fuel wood has accelerated deforestation. Similarly, Brink and Eva [83] reported a massive increase of agricultural land in East African drylands over the period 1975-2000 by at least $123,413 \mathrm{ha}$ at the expense of forests ( $71,325 \mathrm{ha})$ and natural grassland vegetation $(58,894 \mathrm{ha})$. A study done by Wasige et al. [84], noted LULC changes in Kagera Basin, spanning across Burundi, Rwanda, Uganda, and Tanzania between 1901 and 2010. Their study indicated a decline in natural savanna grassland by $15.4 \%$ between 1901 and 2010 while cultivated land increased considerably. Amsalu et al. [85] and Gessesse [86], warned that land use change is brutal, with agricultural land areas in Ethiopia expanding at the expense of natural vegetation cover into marginal areas without any appropriate conservation measures. A similar negative feedback can be seen in our study, where grassland area increased following years of heavy rains, leading to increased livestock keeping, which in turn resulted in overgrazing and decreased woody cover.

The increased open water area between 2000 and 2010 reflects improved hydrology and water storage afforded by farmers' increased water harvesting and reafforestation measures. This agrees with studies conducted by Du et al. [87] who reported that water bodies increased from 125,369 to 1,315,574 ha, at an annual growth rate of 12,389 hectares per year in Jiangsu Province of China during 2000-2005. Settlements have increased in the County following population increase and urbanization, stimulated in part by national decentralization initiatives [44]. The population of West Pokot County (which was a District until 2010) has increased drastically but steadily, from 158,652 in the 1979 census, to 225,449 in 1989, 308,086 in 1999, and 512,690 in 2009 [88,89]; a net increase of $223 \%$ over the 30 -year period, or $+7.44 \%$ per annum.

\subsection{The Phenology of Agricultural Vegetation in West Pokot County}

The consistent increase in vegetation greenness in the NDVI time series in West Pokot County corresponds with the rainfall patterns of the seasonal calendar [90,91]. Pricope et al., [92] also stated that in the horn of Africa, the spatial distribution of NDVI is directly related to precipitation and terrain. In a similar study conducted in the Turkana area, Omondi [93] found that the peaks and lows of the vegetation greenness naturally represented the rainy and dry periods and that there was a good correlation occurred between average rainfall and NDVI for monthly data with a trend of increasing NDVI with rainfall. Omondi added that NDVI has stronger linkages with monthly rainfall anomalies than any other climatic variable. However, a study conducted by Regmi et al. [94] in Nepal did not find a significant correlation between NDVI, temperature, and precipitation. Topographical effects may affect the correlation coefficient between NDVI and climatic parameters [95].The author indicates that caution is required when assessing correlation with NDVI in such specific locations.

The low NDVI values for West Pokot from January to February partly reflected the harvesting and land preparation that takes place in these months. The NDVI peak in June corresponded with the maturing of crops planted during the long rains (from March to May) to grow with sufficient soil moisture. The decrease in NDVI values from June to July followed the reduction in greenness as these same crops were harvested. Land preparation and planting begin anew in August until September as the short rains begin, hence the 
stable but lower NDVI values reflecting bare land and plants which have not germinated from the ground. Harvesting of these second crops started in November, which accounted for decreasing NDVI and greenness. This means that prolonged dry-spells during cropping seasons directly impact the performance of crop production [96]. Alternating dry-spells occurring and exceeding the same durations show the high risks and vulnerability that rain-fed smallholder farmers are exposed to in the study area [96]. Often, prolonged dryspells are accompanied by poor distribution and low soil moisture for plant growth during the growing season.

Although April-May and August were the peak rainfall months in the study locations, June and September were the peak NDVI months, meaning there was a roughly one-month lag period. Previous studies by Anyamba et al. [97] reported a 1-3 months lagged response of rainfall and NDVI in Eastern Africa after the 1997/ 1998 El Niño event, 1 month in West Africa, and 1.5 months in Southern Africa [98]. The lag showed that vegetation does not respond directly to rainfall, but rather to soil moisture, which is a multi-month integral of rainfall [99].

\subsection{Perceptions of the Relationships between Food Insecurity and Climate Change and Variability} in West Pokot County

\subsubsection{Perception of climate change and climate variability in West Pokot County}

Delayed onset and early cessation of rainfall and increased temperatures were variables more recognized by respondents than the total rainfall amount in a season. This perception conforms with empirical evidence from agronomic studies $[100,101]$. There was more consistency among observations related to temperature increase and climate data.

Respondents agreed most about an apparent decrease in the amount of rainfall. These results agree with several studies including those of [102-104] where communities in Mexico, East Africa, and India, perceived a decrease in rainfall amount and duration. Other studies [105-107] found that more than 50\% of the respondents asserted rains were decreasing. Even though our findings agree with this other research, the local perception of a decreasing rainfall trend was not supported by meteorological data. The dataset shows no discernible trend, suggesting that respondents were instead influenced by variability in rainfall between years and extreme events. This could also be attributed to their observations of crop stress, dry fields, and drought causing them to link such observations with perceived reductions in rainfall [108], or with their recent experiences of flood/drought/poor rain associated with increased climate variability [109-111].

Similarly, Mulenga and Wineman [112] noted a clear overlap between farmers' observations and patterns found in the meteorological records. Slegers [113] found that farmers in Africa hold a definition of drought that is broader than a simple lack of rain. Rather, they focus on the aggregated impact of multiple climate variables. Farmers' memory of past events can be faulty as well as their failure to differentiate between climate (the statistical expectation) and weather (what we get) patterns [114]. However, a study by Tierney et al. [115] supported the findings of the recent decrease in rainfall over the Greater Horn of Africa (GHA), especially during the long rains. Liebmann et al. [103] reported a decrease in rainfall during the period of 1979-2005 over East Africa. Analytical results for Kenya indicate that the precipitation in Kenya is not uniformly distributed through time and space [116].

\subsubsection{Perception of Impacts of Climate Change and Variability on Crop Productivity}

Respondents perceived that temperature increase and rainfall variations reduced crop production, particularly of maize, which is a staple in the area. This agrees with other studies [31,117-119] in SSA showing evidence of negative climate change impact on crop yield including maize, a major staple cereal food crop, with huge implications for the arid and semi-arid regions [120]. This might, however, relate to the changes in management rather than climate change, such as the increasing efforts to grow maize in larger areas and in more marginal environments with no or insufficient new inputs to 
maintain it. Nevertheless, some of the studies [121,122] have acknowledged the interplay of other non-climatic factors as well. Kangalawe et al. [122] stressed the need to quantify the magnitude of impacts of climate change and isolate them from non-climatic factors with compounding effects. They noted that it may not be possible to separate the impacts of climatic and non-climatic factors on crop production and agriculture entirely as they interact and intertwine with each other generating impact.

Impacts on crop productivity were more notable in the lowlands and some parts of the midlands than in the higher potential highlands. This could be associated with the recent, repeated drought events restricting crop production or could be linked to various environmental changes (temperature increase, rainfall irregularity, degradation of soil structure, etc.) that reduced water availability and agricultural yield in the dry lowland areas. Kalungu and Harris [123], in their study of climate variability in the semi-arid and sub-humid regions of Kenya showed that 74.4\% of farmers in the semi-arid region perceived changes in crop productivity for the past 10 years against $57.85 \%$ of farmers from the sub-humid region. IPCC [2] had indicated that crop productivity in low tropical and dry areas is projected to decrease with an increase in temperature of $1{ }^{\circ} \mathrm{C}$ to $2{ }^{\circ} \mathrm{C}$. Even though Fischer and van Velthuizen [124] indicated that the overall impacts of climate change on food production will have a positive impact on food, results will vary by region. Jones and Thorton [125] showed that maize production in Africa and Latin America would reduce by $10 \%$ by 2055 and recommended that climate change impacts be assessed at the household level so that the poor who depend on agriculture can be targeted for advice.

Rainfall variability, particularly during the short rains season, is the major constraint noted in West Pokot. Unreliable short rain harvests mean many households now rely exclusively on the harvests from a single, long rains crop production each year. Ngigi [126] also noted that most areas characterized by low and erratic rainfall, concentrated in one or two rainy seasons may result in high risk of droughts, intra- and off-seasonal dry spells, and frequent food insecurity.

\subsubsection{Perception of Weather Forecast Information}

The respondents practiced their farming with minimal knowledge of the ongoing climate changes and possible impacts on seasonal weather, meaning they may not be adequately empowered to respond and adapt to the projected magnitude of these changes. Gwimbi's [127] study in the Gokwe District of Zimbabwe found that more than 70 percent of the surveyed farmers lacked access to timely weather forecasts. Ziervogel et al. [128] and Lemos and Dilling [129] highlighted that forecasts had not been extensively embraced and their effective utilization has lagged, particularly in marginal areas. The range of information sources in West Pokot was extremely limited, unlike other studies conducted in Bangladesh, Ghana, and Uganda by Chaudhury et al. [130], which found diverse information sources such as radios, newspapers, mobile phones, public announcements at schools and during religious gatherings, and print media as important channels. Cherotich, et al. [131] argued that the choice of the dissemination channels could influence access and use of climate information and service disseminated enable the vulnerable groups exposed to climatic hazards to build adequate response capacities. Education has contributed to imparting awareness among people [132].

Hansen et al. [133] reported that radio and ICT-based communication offer immense potential to support the delivery of climate information support services, but cannot replace the trust, visual communication of location-specific information, feedback, and mutual learning that face-to-face interaction provides. The use of ICT in West Pokot was however very low. Ballantyne, Labelle, and Rudgard [134] contend that the use of ICTs in rural areas is limited by lack of awareness, skills, training, and a shortage of capital resources for sustainability. Our respondents had more confidence in traditional forecasters than radio because to them, these predictions are location-specific. Indeed, even existing scientific data have issues accurately predicting some parameters, such as the duration and coverage 
of drought [135], which in some places is aggravated by the fact that the forecasts are not location-specific [136].

Other studies have argued that some farmers who prepare their land and plant their crops based on traditional prediction techniques are forced to replant them due to an unexpected dry spell after the early rains $[137,138]$. On one hand, some scholars feel skeptical about the accuracy and reliability of traditional prediction methods under current weather and climate change and variability [139,140]. Others [141,142] acknowledged and emphasized the importance and use of local knowledge for weather and climate prediction, decision making, climate change adaptation [143,144], and to complement scientific information $[140,145,146]$.

\subsection{Measures Taken to Reduce Climate Change Impacts on Food Security}

Apart from receiving relief food, the people of West Pokot are employing other coping mechanisms, however men took more measures than women. This could be attributed to patriarchal land ownership rights in the area affecting adaptation decisions, and agrees with [147] that different socio-economic, environmental, and institutional factors affect the climate change perception and adaptive behavior of farmers. Nelson et al., [148] notes that existing gender imbalances in agriculture mean that women are potentially at a comparative disadvantage in terms of participating in and benefiting from site-specific climate actions on the ground. As observed in other studies in the Upper West Region of Ghana, female farmers showed preference for adaptation measures that have benefits that could be realized in the short-term because of the constraints they faced in accessing productive resources such as land and labor $[149,150]$. This suggests the need for incorporating gender-based assessment of climate change adaptation in planning for adaptation interventions [151].

Dependence on relief food is highly regarded as a coping strategy by the Pokots. In the years characterized by prolonged drought and famine, many Pokot families relied on famine relief for survival. For example, in 1980 and 1981 which had minimal rains [152] and the 1984/85 period [153], West Pokot benefited from famine relief and food aid. In 2013, the county suffered massive flooding that submerged untold hectares of maize, millet, and sorghum, and was therefore, supplied with relief food [154]. In 2015 and 2016, 600,000 residents faced acute hunger as the maize crops withered and livestock starved under extreme heat and lack of rainfall in the long rain season [154]. In 2017, over 40,000 residents were in dire need of water and food in West Pokot [155].

Drought mitigation strategies including relief are deemed to improve socio-economic conditions, reduce pressure on land (crop and grazing), and reduce vulnerability [156]. The Pokots could opt for relief food due to inadequate production to feed the population and a lack of adequate coping mechanisms [153]. However, this is a short-term solution and increases the level of dependence in the long-term [153], without protecting them against a recurrence of hunger or enabling greater self-sufficiency [157].

\section{Conclusions}

The results confirm that the climate in West Pokot has changed and is already having implications for food security. Semi-arid regions are inherently dynamic, with high degrees of interannual and spatial variability, but increased uncertainty and variability amplify the vulnerabilities of existing farming systems. While respondents might attribute perceived changes in local vegetation to climate changes, the GIS and rainfall data suggest that human-induced conversion is more likely responsible for converting grassland/forestland to cropland. As these conversions interact with ongoing climate change and variability, the competing land uses involving forestland, cropland, settlements, wetlands, and grassland, are likely driving the system toward a less viable use of the environment. NDVI correlates with rainfall received, with a one-month lag, and can be useful in monitoring and managing drought on a near real-time basis and in trend analysis. The observed NDVI trends in West Pokot, however, cannot be exclusively explained by rainfall anomalies, since there are other human factors that impact vegetation dynamics including LULC change. 
The local populations are responding to the perceived changes in diverse ways, which means strategies for adaptation cannot be generalized and should be more site-specific. Policymakers and development agencies should focus on formulating and implementing policies and programs that minimize overreliance on relief food and promote farm-level adaptation strategies such as agroforestry, reforestation, and climate smart agriculture where drought-resistant trees and crops could be introduced or encouraged according to the agroecological zone. Trade-offs between increasing cropland and the subsequent reduction in grassland as a coping strategy by the Pokots need be investigated in terms of socio-economic and ecological sustainability, and their effects on other ecosystem services. GIS and climate data can be used to complement the existing local knowledge.

Better quality, timely, and site-specific scientific weather forecasts could help bolster local knowledge systems and adaptation practices. This study showed that at present, West Pokot people have little access to, and make minimal use of, weather information, and deem its present value quite low. Increasing the availability of weather stations at the local level and enhancing the capacity to collect and analyze weather information could enhance appropriate adaptation strategies. Farmers will appreciate timely information on the amount and distribution of rainfall and the expected time of onset and cessation during cropping seasons. The government should support continuous climate change monitoring, intensified early warning systems, and the dissemination of relevant information to farmers. Further research could focus on investigating climate variables and human-induced factors in vegetation variability, as well as the long-term monitoring of the arid ecosystems.

Author Contributions: Conceptualization, E.B.O., J.J.R.; methodology, E.B.O., J.J.R., L.D.; formal analysis, E.B.O., L.O.; writing-original draft preparation, E.B.O., J.J.R., L.D.; writing-review and editing, E.B.O., J.J.R., L.D., L.O. All authors have read and agreed to the published version of the manuscript.

Funding: The field research was funded by the Canadian Social Sciences and Humanities Research Council (SSHRC), under the grant \# 410-2011-2323 ("Global Climate Change and Kenya: Vulnerability and Adaptation of Livelihoods Under Environmental Stresses (VALUES)").

Institutional Review Board Statement: The study was approved by the Research Ethics Board of the University of Ottawa (file 05-12-19B).

Informed Consent Statement: Informed consent was obtained from all subjects involved in the study.

Data Availability Statement: Data is available upon request from the lead author.

Acknowledgments: This research was made possible by the kindness, patience, and hospitality of the people of West Pokot. Thanks also to Obade, Koske, and Kung'u of Kenyatta University for their honest guidance and constructive criticism of earlier versions of this research, and to four anonymous reviewers who improved earlier drafts of this paper. Despite the good efforts of these many people, the authors must remain accountable for any deficiencies in the final product.

Conflicts of Interest: The authors declare no conflict of interest.

\section{References}

1. Parry, M.L.; Rosenzweig, C.; Iglesias, A.; Livermore, M.; Fischer, G. Effects of climate change on global food production under SRES emissions and socio-economic scenarios. Glob. Environ. Chang. 2004, 14, 53-67. [CrossRef]

2. IPCC. Climate Change 2007-The Physical Science Basis: Working Group I Contribution to the Fourth Assessment Report of the IPCC (Climate Change 2007); Solomon, S., Qin, D., Manning, M., Marquis, M., Averyt, K., Tignor, M.M.B., Miller, H.L., Chen, Z., Eds.; IPCC: Geneva, Switzerland; Cambridge University Press: New York, NY, USA, 2007; ISBN 0521705967.

3. Ojwang', G.O.; Agatsiva, J.; Situma, C. Analysis of Climate Change and Variability Risks in the Smallholder Sector; Case studies of the Laikipia and Narok Districts Representing Major Agro-Ecological Zones in Kenya; Department of Resource Surveys and Remote Sensing (DRSRS) and FAO: Rome, Italy, 2010.

4. Belloumi, M. Investigating the linkage between climate variables and food security in ESA countries. Reg. Environ. Chang. 2014, 42, 172-186.

5. Mongi, H.; Majule, A.E.; Lyimo, J.G. Vulnerability and adaptation of rain fed agriculture to climate change and variability in semi-arid Tanzania. Afr. J. Environ. Sci. Technol. 2010, 4, 371-381. 
6. Mesike, C.S.; Esekhade, T.U. Rainfall variability and rubber production in Nigeria. African J. Environ. Sci. Technol. 2014, 8, 54-57. [CrossRef]

7. International Water Management Institute (IWMI). Managing Water for Rainfed Agriculture; International Water Management Institute (IWMI): Colombo, Sri Lanka, 2010. [CrossRef]

8. Krishnamurthy, P.K.; Hobbs, C.; Matthiasen, A.; Hollema, S.R.; Choularton, R.J.; Pahari, K.; Kawabata, M. Climate Risk and Food Security in Nepal-Analysis of Climate Impacts on Food Security and Livelihoods; CGIAR Research Program on Climate Change, Agriculture and Food Security (CCAFS): Copenhagen, Denmark, 2013. Available online: https://ccafs.cgiar.org/resources/ publications / climate-risk-and-food-security-nepal-analysis-climate-impacts-food (accessed on 10 September 2021).

9. Technical Centre for Agricultural and Rural Cooperation. Spore Special Issue: Climate Change. Available online: https: / / cgspace.cgiar.org/handle/10568/76898 (accessed on 10 September 2021).

10. Adams, R.M.; West, J.A.E. The implications of global change for western agriculture. West. J. Agric. Econ. 1988, 13, 348-356.

11. Jat, M.L.; Stirling, C.M.; Jat, H.S.; Tetarwal, J.P.; Jat, R.K.; Singh, R.; Lopez-Ridaura, S.; Shirsath, P.B. Soil processes and wheat cropping under emerging climate change scenarios in South Asia. Adv. Agron. 2018, 148, 111-171.

12. Vigren Skogseid, M. Climate Change in Kenya: A Review of Literature and Evaluation of Temperature and Precipitation Data. Bachelor's Thesis, Lund University, Lund, Sweden, 2017.

13. Fazal, S.A.; Wahab, S.A. Economic Impact of Climate Change on Agricultural Sector: A review. J. Transform. Entrep. 2013, 1, 39-49.

14. FAO. Climate Change and Food Security: A Framework Document; Food and Agricultural Organization of United Nation: Rome, Italy, 2008.

15. Chuen Khee, P.; Yet Mee, L.; Chee Keong, C. The Economic Impact of Climate Change on Food Security in Malaysia; University Library of Munich: Munich, Germany, 2011.

16. Neufeldt, H.; Kristjanson, P.; Thorlakson, T.; Gassner, A.; Norton-Griffiths, M.; Place, F.; Langford, K. Making Climate-Smart Agriculture Work for the Poor; World Agroforestry Centre (ICRAF): Nairobi, Kenya, 2011.

17. FAO; IFAD; UNICEF; WFP; WHO. The State of Food Security and Nutrition in the World 2017. Building Resilience for Peace and Food Security; FAO: Rome, Italy, 2017; ISBN 978-92-5-109888-2. Available online: www.fao.org/3/a-I7695e.pdf (accessed on 10 September 2021).

18. Wheeler, T.; von Braun, J. Climate change impacts on global food security. Science 2013, 341, 508-513. [CrossRef]

19. Rötter, R.; Sehomi, F.; Höhn, J.; Niemi, J.; den Berg, M. On the Use of Agricultural System Models for Exploring Technological Innovations Across Scales in Africa: A Critical Review; University of Bonn, Center for Development Research (ZEF): Bonn, Germany, 2016.

20. Stocker, T.; Qin, D.; Plattner, G.; Tignor, M.; Allen, S.; Boschung, J.; Nauels, A.; Xia, Y.; Bex, V.; Midgley, P. IPCC, 2013: Summary for Policymakers in Climate Change 2013: The Physical Science Basis, Contribution of Working Group I to the Fifth Assessment Report of the Intergovernmental Panel on Climate Change; Cambridge University Press: New York, NY, USA, 2013.

21. Arndt, C.; Farmer, W.; Strzepek, K.; Thurlow, J. Climate Change, Agriculture and Food Security in Tanzania; The United Nations University World Institute for Development Economics Research (UNU-WIDER): Helsinki, Finland, 2011.

22. Manei, N. Integration of Indigenous Knowledge with Information and Communication Technologies in Coping with Effects of Climate Change and Variability on Agriculture in Kajiado County, Kenya; University of Nairobi: Nairobi, Kenya, 2013.

23. MEMR (Ministry of Environment and Mineral Resources). National Climate Change Response Strategy: Executive Brief. Minist. Environ. Miner. Resour. Gov. Kenya (GoK), Nairobi. 2010. Available online: http://www.environment.go.ke/wp-content/ documents / complete\%20nccrs\%20executive\%20brief.pdf (accessed on 10 September 2021).

24. USAID. Food Security in Kenya: Situation Report; United States Agency International Development: Nairobi, Kenya, 2013.

25. Asiti, W. Smallholder Farmers' Perception of the Impacts of Climate Change and Variability on Rain-fed Agricultural Practices in Semi-arid and Sub-humid Regions of Kenya; Kenya National Youth Conference on Climate Change: Mbagathi, Kenya, 2010.

26. Mutimba, S.; Mayieko, S.; Olum, P.; Wanyama, K. Climate Change Vulnerability and Adaptation Preparedness in Kenya; Heinrich Böll Stiftung, East and Horn Africa: Nairobi, Kenya, 2010. Available online: http:/ / www.boell.or.ke/downloads/Kenya_Climate_ Change_Adaptation_Preparedness.pdf (accessed on 10 September 2021)ISBN 9966-7172-3-4.

27. Wakibi, S.; Gichuhi, W.; Kabira, W.M. Food Security Score for Kenya. J. Afr. Women's Stud. Cent. 2015, 1, 1-12.

28. Ng'ang'a, T.K. Women's Experiences on Food Security in Kenya: Major Challenges That They Face. Pathways to African Feminism and Development. J. Afr. Women's Stud. Cent. 2015, 1, 2.

29. Roncoli, C. Ethnographic and participatory approaches to research on farmers' responses to climate predictions. Clim. Res. 2006, 33, 81-99. [CrossRef]

30. Kabubo-Mariara, J.; Kabara, M. Climate change and food security in Kenya. In Agricultural Adaptation to Climate Change in Africa; Routledge: London, UK, 2018; pp. 55-80.

31. Zinyengere, N.; Crespo, O.; Hachigonta, S.; Tadross, M. Local impacts of climate change and agronomic practices on dry land crops in Southern Africa. Agric. Ecosyst. Environ. 2014, 197, 1-10. [CrossRef]

32. Fuchs, L.E.; Orero, L.; Namoi, N.; Neufeldt, H. How to effectively enhance sustainable livelihoods in smallholder systems: A comparative study from Western Kenya. Sustainability 2019, 11, 1564. [CrossRef]

33. Ramisch, J.J. They don't know what they are talking about': Soil fertility knowledge, cognitive dissonance, and experimental practice in western Kenya. Geoforum 2014, 55, 120-132. [CrossRef]

34. Silvestri, S.; Bryan, E.; Ringler, C.; Herrero, M.; Okoba, B. Climate change perception and adaptation of agro-pastoral communities in Kenya. Reg. Environ. Chang. 2012, 12, 791-802. [CrossRef] 
35. Osbahr, H.; Dorward, P.; Stern, R.; Cooper, S. Supporting agricultural innovation in Uganda to respond to climate risk: Linking climate change and variability with farmer perceptions. Exp. Agric. 2011, 47, 293-316. [CrossRef]

36. Simelton, E.; Quinn, C.H.; Batisani, N.; Dougill, A.J.; Dyer, J.C.; Fraser, E.D.G.; Mkwambisi, D.; Sallu, S.; Stringer, L.C. Is rainfall really changing? Farmers' perceptions, meteorological data, and policy implications. Clim. Dev. 2013, 5, 123-138. [CrossRef]

37. Hasan, M.K.; Kumar, L. Comparison between meteorological data and farmer perceptions of climate change and vulnerability in relation to adaptation. J. Environ. Manag. 2019, 237, 54-62. [CrossRef]

38. Peltonen-Sainio, P.; Jauhiainen, L.; Honkavaara, E.; Wittke, S.; Karjalainen, M.; Puttonen, E. Pre-crop values from satellite images for various previous and subsequent crop combinations. Front. Plant Sci. 2019, 10, 462. [CrossRef] [PubMed]

39. Darkoh, M.B.K. Regional perspectives on agriculture and biodiversity in the drylands of Africa. J. Arid Environ. 2003, 54, 261-279. [CrossRef]

40. Cihlar, J.; Laurent, L.S.; Dyer, J.A. Relation between the normalized difference vegetation index and ecological variables. Remote Sens. Environ. 1991, 35, 279-298. [CrossRef]

41. Ma, M.; Frank, V. Interannual variability of vegetation cover in the Chinese Heihe River Basin and its relation to meteorological parameters. Int. J. Remote Sens. 2006, 27, 3473-3486. [CrossRef]

42. Nagai, S.; Ichii, K.; Morimoto, H. Interannual variations in vegetation activities and climate variability caused by ENSO in tropical rainforests. Int. J. Remote Sens. 2007, 28, 1285-1297. [CrossRef]

43. Mabuchi, K.; Sato, Y.; Kida, H. Climatic impact of vegetation change in the Asian tropical region. Part I: Case of the Northern Hemisphere summer. J. Clim. 2005, 18, 410-428. [CrossRef]

44. West Pokot County. West Pokot County Integrated Development Plan, CIDP (2018-2022); West Pokot County: Kapenguria, Kenya, 2018.

45. Ogola, E.O.; Chepkorir, E.; Sang, R.; Tchouassi, D.P. A previously unreported potential malaria vector in a dry ecology of Kenya Parasites Vectors 2019, 12, 1-6. [CrossRef]

46. West Pokot County. West Pokot County Integrated Development Plan, CIDP (2013-2017); West Pokot County: Kapenguria, Kenya, 2013.

47. Israel, G.D. Sampling the Evidence of Extension Program Impact; Program evaluation and organizational development, IFAS, University of Florida: Gainesville, FL, USA, 1992.

48. Cox, D.R. Two Further Applications of a Model for Binary Regression. Biometrika 1958, 45, 562-565. [CrossRef]

49. Amber, C. ERDAS 2011 Software. GeoInformatics 2011, 4, 32-34. Available online: https://www.gim-international.com/content/ news/erdas-2011-software (accessed on 10 September 2021).

50. ArcGIS [GIS Software]; Version 10.0; Environmental Systems Research Institute, Inc.: Redlands, CA, USA, 2010. Available online: https: / / enterprise.arcgis.com/en/portal/10.3/use/copyright-information.htm (accessed on 10 September 2021).

51. IPCC. 2006 National Greenhouse Gas Inventory Guidelines; Eggelston, S., Buendia, L., Miwa, K., Ngara, T., Tanabe, K., Eds.; IPCC: Kanagawa, Japan, 2006.

52. R Core Team. R: A Language and Environment for Statistical Computing. R Foundation for Statistical Computing, Vienna, Austria. 2021. Available online: https://www.R-project.org (accessed on 10 September 2021).

53. Wickham, H.; Averick, M.; Bryan, J.; Chang, W.; McGowan, L.D.; François, R.; Grolemund, G.; Hayes, A.; Henry, L.; Hester, J.; et al. Welcome to the \{tidyverse\}. J. Open Source Softw. 2019, 4, 1686. [CrossRef]

54. Wickham, H.; Seidel, D. scales: Scale Functions for Visualization. R Package Version 1.1.1. 2020. Available online: https: / /CRAN.Rproject.org / package=scales (accessed on 10 September 2021).

55. Zeileis, A.; Grothendieck, G. zoo: S3 Infrastructure for Regular and Irregular Time Series. J. Stat. Softw. 2005, 14, 1-27. [CrossRef]

56. De Mendiburu, F. Agricolae: Statistical Procedures for Agricultural Research. R Package, Version 1.3-5. 2021. Available online: https: / /CRAN.R-project.org/package=survival (accessed on 10 September 2021).

57. Luedeling, E.; Sileshi, G.; Dietz, J. Advances in Agroforestry. In Advances in Agroforestry; Kumar, B.M., Nair, P.K.R., Eds.; Springer Science and Business Media: New York, NY, USA, 2011; pp. 61-83.

58. Fox, J.; Weisberg, S. An \{R\} Companion to Applied Regression, 3rd ed.; Sage: Thousand Oaks, CA, USA, 2019. Available online: https:/ / socialsciences.mcmaster.ca/jfox/Books/Companion/ (accessed on 10 September 2021).

59. Hyndman, R.; Athanasopoulos, G.; Bergmeir, C.; Caceres, G.; Chhay, L.; O'Hara-Wild, M.; Petropoulos, F.; Razbash, S.; Wang, E.; Yasmeen, F. \{forecast\}: Forecasting Functions for Time Series and Linear Models. 2021. R Package, Version 8.15. Available online: https://pkg.robjhyndman.com/forecast/ (accessed on 10 September 2021).

60. Collins, J.M. Temperature variability over Africa. J. Clim. 2011, 24, 3649-3666. [CrossRef]

61. Ogutu, J.O.; Piepho, H.-P.; Said, M.Y.; Ojwang, G.O.; Njino, L.W.; Kifugo, S.C.; Wargute, P.W. Extreme wildlife declines and concurrent increase in livestock numbers in Kenya: What are the causes? PLoS ONE 2016, 11, e0163249.

62. Issahaku, A.-R.; Campion, B.B.; Edziyie, R. Rainfall and temperature changes and variability in the Upper East Region of Ghana. Earth Sp. Sci. 2016, 3, 284-294. [CrossRef]

63. Bonfils, S. Trend analysis of the mean annual temperature in Rwanda during the last fifty two years. J. Environ. Prot. 2012, 3 , 538-551. [CrossRef]

64. King'Uyu, S.M.; Ogallo, L.A.; Anyamba, E.K. Recent trends of minimum and maximum surface temperatures over Eastern Africa. J. Clim. 2000, 13, 2876-2886. [CrossRef]

65. Kurukulasuriya, P. Economic Impact of Climate Change on African Agriculture; Yale University: New Haven, CT, USA, 2006. 
66. Conway, D.; Schipper, E.L.F. Adaptation to climate change in Africa: Challenges and opportunities identified from Ethiopia. Glob. Environ. Chang. 2011, 21, 227-237. [CrossRef]

67. Hulme, M.; Doherty, R.; Ngara, T.; New, M.; Lister, D. African climate change: 1900-2100. Clim. Res. 2001, 17, 145-168. [CrossRef]

68. Teixeira, E.I.; Fischer, G.; Van Velthuizen, H.; Walter, C.; Ewert, F. Global hot-spots of heat stress on agricultural crops due to climate change. Agric. For. Meteorol. 2013, 170, 206-215. [CrossRef]

69. Ainsworth, E.A.; Ort, D.R. How do we improve crop production in a warming world? Plant Physiol. 2010, 154, 526-530. [CrossRef]

70. Belachew, A. Dry-Spell Analysis for Studying the Sustainability of Rain-Fed Agriculture in Ethiopia: The Case of the Arbaminch Area; International Commission on Irrigation and Drainage (ICID): New Delhi, India; Institute for the Semi-Arid Tropics, Direction de la Meteorology Nationale du Niger: Addis Ababa, Ethiopia, 2000.

71. Akponikpe, P.B.I.; Michels, K.; Bielders, C.L. Integrated nutrient management of pearl millet in the Sahel combining cattle manure, crop residue and mineral fertilizer. Exp. Agric. 2008, 44, 453-472. [CrossRef]

72. Mzezewa, J.; Misi, T.; Van Rensburg, L. Characterisation of rainfall at a semi-arid ecotope in the Limpopo Province (South Africa) and its implications for sustainable crop production. Water 2010, 36, 19-26. [CrossRef]

73. Githui, F.; Gitau, W.; Mutua, F.; Bauwens, W. Climate change impact on SWAT simulated streamflow in western Kenya. Int. J. Climatol. A J. R. Meteorol. Soc. 2009, 29, 1823-1834. [CrossRef]

74. Rao, K.P.C.; Verchot, L.V.; Laarman, J. Adaptation to Climate Change through Sustainable Management and Development of Agroforestry Systems. J. SAT Agric. Res. 2007, 4, 1-30.

75. Watson, R.T.; Zinyowera, M.C.; Moss, R.H.; Dokken, D.J. The Regional Impacts of Climate Change: An Assessment of Vulnerability; Cambridge University Press: Cambridge, UK, 1998.

76. IPCC. Climate Change 2007: Synthesis Report. Contribution of Working Groups I, II and III to the Fourth Assessment Report of the Intergovernmental Panel on Climate Change; Core Writing Team, Pachauri, R.K., Reisinger, A., Eds.; IPCC: Geneva, Switzerland, 2007.

77. Funk, C.C.; Brown, M.E. Declining global per capita agricultural production and warming oceans threaten food security. Food Secur. 2009, 1, 271-289. [CrossRef]

78. Lyon, B.; Vigaud, N. Unraveling East Africa's climate paradox. Clim. Extrem. Patterns Mech. 2017, $265,281$.

79. How Jin Aik, D.; Ismail, M.H.; Muharam, F.M.; Alias, M.A. Evaluating the impacts of land use/land cover changes across topography against land surface temperature in Cameron Highlands. PLoS ONE 2021, 16, e0252111.

80. Fall, S.; Niyogi, D.; Gluhovsky, A.; Pielke Sr, R.A.; Kalnay, E.; Rochon, G. Impacts of land use land cover on temperature trends over the continental United States: Assessment using the North American Regional Reanalysis. Int. J. Climatol. 2010, 30, 1980-1993. [CrossRef]

81. Ministry of Environment and Mineral Resources (MEMR). Master Plan for the Conservation and Sustainable Management of Water Catchment Areas of Kenya; Government of Kenya: Nairobi, Kenya, 2012.

82. County Government of West Pokot. West Pokot County Annual Development Plan 2015/2016; County Government of West Pokot: Kapenguria, Kenya, 2014.

83. Brink, A.B.; Eva, H.D. Monitoring 25 years of land cover change dynamics in Africa: A sample based remote sensing approach. Appl. Geogr. 2009, 29, 501-512. [CrossRef]

84. Wasige, J.E.; Groen, T.A.; Smaling, E.; Jetten, V. Monitoring basin-scale land cover changes in Kagera Basin of Lake Victoria using ancillary data and remote sensing. Int. J. Appl. Earth Obs. Geoinf. 2013, 21, 32-42. [CrossRef]

85. Amsalu, A.; Stroosnijder, L.; de Graaff, J. Long-term dynamics in land resource use and the driving forces in the Beressa watershed, highlands of Ethiopia. J. Environ. Manag. 2007, 83, 448-459. [CrossRef]

86. Dessie, G.; Kleman, J. Pattern and magnitude of deforestation in the South Central Rift Valley Region of Ethiopia. Mt. Res. Dev. 2007, 27, 162-168. [CrossRef]

87. Du, X.; Jin, X.; Yang, X.; Yang, X.; Zhou, Y. Spatial pattern of land use change and its driving force in Jiangsu Province. Int. J. Environ. Res. Public Health 2014, 11, 3215-3232. [CrossRef]

88. Kahuthu, R.; Muchoki, C.; Nyaga, C. Kakamega District Strategic Plan 2005-2010 for Implementation of the National Population Policy for Sustainable Development; National Coordinating Agency for Population and Development (NCAPD): Nairobi, Kenya, 2005.

89. KNBS (Kenya National Bureau of Statistics). 2009 Kenya Population and Housing Census; KNBS: Nairobi, Kenya, 2010.

90. Ministry of State for Development of Northern Kenya and Other Arid Lands Arid Lands Resource Management Project II, Office of The Prime Minister. West Pokot Drought Monitoring Bulletin; Government of the Republic of Kenya, Ministry of State for Development of Northern Kenya and Other Arid Lands Arid Lands Resource Management Project II, Office of The Prime Minister: Nairobi, Kenya, 2010.

91. Chu, D.; Lu, L.; Zhang, T. Sensitivity of normalized difference vegetation index (NDVI) to seasonal and interannual climate conditions in the Lhasa area, Tibetan plateau, China. Arctic, Antarct. Alp. Res. 2007, 39, 635-641. [CrossRef]

92. Pricope, N.G.; Husak, G.; Lopez-Carr, D.; Funk, C.; Michaelsen, J. The climate-population nexus in the East African Horn: Emerging degradation trends in rangeland and pastoral livelihood zones. Glob. Environ. Chang. 2013, 23, 1525-1541. [CrossRef]

93. Omondi, P.A.; Awange, J.L.; Forootan, E.; Ogallo, L.A.; Barakiza, R.; Girmaw, G.B.; Fesseha, I.; Kululetera, V.; Kilembe, C.; Mbati, M.M.; et al. Changes in temperature and precipitation extremes over the Greater Horn of Africa region from 1961 to 2010. Int. J. Climatol. 2014, 34, 1262-1277. [CrossRef]

94. Regmi, R.; Ma, Y.; Ma, W.; Baniya, B.; Bashir, B. Interannual Variation of NDVI, Precipitation and Temperature during the Growing Season in Langtang National Park, Central Himalaya, Nepal. Appl. Ecol. Environ. Sci. 2020, 8, 218-228. 
95. Achard, F.; Estreguil, C. Forest classification of Southeast Asia using NOAA AVHRR data. Remote Sens. Environ. 1995, 54, 198-208. [CrossRef]

96. Kisaka, M.O.; Mucheru-Muna, M.; Ngetich, F.K.; Mugwe, J.N.; Mugendi, D.; Mairura, F. Rainfall variability, drought characterization, and efficacy of rainfall data reconstruction: Case of Eastern Kenya. Adv. Meteorol. 2015, 2015. [CrossRef]

97. Anyamba, A.; Tucker, C.J. Analysis of Sahelian vegetation dynamics using NOAA-AVHRR NDVI data from 1981-2003. J. Arid Environ. 2005, 63, 596-614. [CrossRef]

98. Martiny, N.; Camberlin, P.; Richard, Y.; Philippon, N. Compared regimes of NDVI and rainfall in semi-arid regions of Africa. Int. J. Remote Sens. 2006, 27, 5201-5223. [CrossRef]

99. Malo, A.R.; Nicholson, S.E. A study of rainfall and vegetation dynamics in the African Sahel using normalized difference vegetation index. J. Arid Environ. 1990, 19, 1-24. [CrossRef]

100. Barron, J.; Rockström, J.; Gichuki, F.; Hatibu, N. Dry spell analysis and maize yields for two semi-arid locations in east Africa. Agric. For. Meteorol. 2003, 117, 23-37. [CrossRef]

101. Harvest Choice Rainfall Variability and Crop Yield Potential; International Food Policy Research Institute: Washington, DC, USA; University of Minnesota: St. Paul, MN, USA, 2010.

102. Sánchez-Cortés, M.S.; Chavero, E.L. Indigenous perception of changes in climate variability and its relationship with agriculture in a Zoque community of Chiapas, Mexico. Clim. Chang. 2011, 107, 363-389. [CrossRef]

103. Liebmann, B.; Hoerling, M.P.; Funk, C.; Bladé, I.; Dole, R.M.; Allured, D.; Quan, X.; Pegion, P.; Eischeid, J.K. Understanding recent eastern Horn of Africa rainfall variability and change. J. Clim. 2014, 27, 8630-8645. [CrossRef]

104. Howe, P.D.; Thaker, J.; Leiserowitz, A. Public perceptions of rainfall change in India. Clim. Chang. 2014, 127, 211-225. [CrossRef]

105. Ahmed, S.A.; Diffenbaugh, N.S.; Hertel, T.W.; Lobell, D.B.; Ramankutty, N.; Rios, A.R.; Rowhani, P. Climate volatility and poverty vulnerability in Tanzania. Glob. Environ. Chang. 2011, 21, 46-55. [CrossRef]

106. Below, T.B.; Schmid, J.C.; Sieber, S. Farmers' knowledge and perception of climatic risks and options for climate change adaptation: A case study from two Tanzanian villages. Reg. Environ. Chang. 2015, 15, 1169-1180. [CrossRef]

107. Rowhani, P.; Lobell, D.B.; Linderman, M.; Ramankutty, N. Climate variability and crop production in Tanzania. Agric. For. Meteorol. 2011, 151, 449-460. [CrossRef]

108. Chen, D.; Whalen, J.K. Climate change in the North China Plain: Smallholder farmer perceptions and adaptations in Quzhou County, Hebei Province. Clim. Res. 2016, 69, 261-273. [CrossRef]

109. Kassie, B.T.; Hengsdijk, H.; Rötter, R.; Kahiluoto, H.; Asseng, S.; Van Ittersum, M. Adapting to climate variability and change: Experiences from cereal-based farming in the Central Rift and Kobo Valleys, Ethiopia. Environ. Manag. 2013, 52, $1115-1131$. [CrossRef]

110. Le Dang, H.; Li, E.; Nuberg, I.; Bruwer, J. Understanding farmers' adaptation intention to climate change: A structural equation modelling study in the Mekong Delta, Vietnam. Environ. Sci. Policy 2014, 41, 11-22. [CrossRef]

111. Panda, A. Exploring climate change perceptions, rainfall trends and perceived barriers to adaptation in a drought affected region in India. Nat. Hazards 2016, 84, 777-796. [CrossRef]

112. Mulenga, B.P.; Wineman, A.; Sitko, N.J. Climate trends and farmers' perceptions of climate change in Zambia. Environ. Manag. 2017, 59, 291-306. [CrossRef]

113. Slegers, M.F.W. "If only it would rain": Farmers' perceptions of rainfall and drought in semi-arid central Tanzania. J. Arid Environ. 2008, 72, 2106-2123. [CrossRef]

114. Moyo, M.; Mvumi, B.M.; Kunzekweguta, M.; Mazvimavi, K.; Craufurd, P.; Dorward, P. Farmer perceptions on climate change and variability in semi-arid Zimbabwe in relation to climatology evidence. African Crop Sci. J. 2012, 20, 317-335.

115. Dunlap, R.E.; Brulle, R.J. Adaptation to climate change. In Climate Change and Society: Sociological Perspectives; Dunlap, R.E.; Brulle, R.J. Oxford University Press: New York, NY, USA, 2015; pp. 164-198. ISBN 13: 9780199356102.

116. Ayugi, B.O.; Wen, W.; Chepkemoi, D. Analysis of spatial and temporal patterns of rainfall variations over Kenya. Studies 2016, 6 , 69-83.

117. Lobell, D.B.; Burke, M.B.; Tebaldi, C.; Mastrandrea, M.D.; Falcon, W.P.; Naylor, R.L. Prioritizing Climate Change Adaptation Needs for Food Security in 2030. Science 2008, 319, 607-610. [CrossRef]

118. Knox, J.; Hess, T.; Daccache, A.; Wheeler, T. Climate change impacts on crop productivity in Africa and South Asia. Environ. Res. Lett. 2012, 7, 034032. [CrossRef]

119. Waha, K.; Müller, C.; Bondeau, A.; Dietrich, J.P.; Kurukulasuriya, P.; Heinke, J.; Lotze-Campen, H. Adaptation to climate change through the choice of cropping system and sowing date in sub-Saharan Africa. Glob. Environ. Chang. 2013, 23, 130-143. [CrossRef]

120. Omoyo, N.N.; Wakhungu, J.; Oteng'i, S. Effects of climate variability on maize yield in the arid and semi arid lands of lower eastern Kenya. Agric. Food Secur. 2015, 4, 1-13. [CrossRef]

121. Mubaya, C.P.; Njuki, J.; Mutsvangwa, E.P.; Mugabe, F.T.; Nanja, D. Climate variability and change or multiple stressors? Farmer perceptions regarding threats to livelihoods in Zimbabwe and Zambia. J. Environ. Manag. 2012, 102, 9-17. [CrossRef]

122. Kangalawe, R.Y.M.; Lyimo, J.G. Climate change, adaptive strategies and rural livelihoods in semiarid Tanzania. Natural Resour. 2013, 4, 266-278. [CrossRef]

123. Kalungu, J.W.; Harris, D. Smallholder farmers' perception of the impacts of climate change and variability on rain-fed agricultural practices in semi-arid and sub-humid regions of Kenya. J. Environ. Earth Sci. 2013, 3, 129-140. 
124. Fischer, G.; van Velthuizen, H.T. Climate Change and Global Agricultural Potential Project: A Case of Kenya; IIASA Working Paper; IIASA: Laxenburg, Austria, 1996.

125. Jones, P.G.; Thornton, P.K. The potential impacts of climate change on maize production in Africa and Latin America in 2055. Glob. Environ. Chang. 2003, 13, 51-59. [CrossRef]

126. Ngigi, S.N. Climate Change Adaptation Strategies: Water Resources Management Options for Smallholder Farming Systems in Sub-Saharan Africa; The Earth Institute at Columbia University: New York, NY, USA, 2009.

127. Gwimbi, P. Cotton farmers' vulnerability to climate change in Gokwe District (Zimbabwe): Impact and influencing factors. JAMBA J. Disaster Risk Stud. 2009, 2, 81-92. [CrossRef]

128. Ziervogel, G. Targeting seasonal climate forecasts for integration into household level decisions: The case of smallholder farmers in Lesotho. Geogr. J. 2004, 170, 6-21. [CrossRef]

129. Lemos, M.C.; Dilling, L. Equity in forecasting climate: Can science save the world's poor? Sci. Public Policy 2007, 34, 109-116. [CrossRef]

130. Chaudhury, M.; Kristjanson, P.M.; Kyagazze, F.; Naab, J.B.; Neelormi, S. Participatory Gender-Sensitive Approaches for Addressing Key Climate Change-Related Research Issues: Evidence from Bangladesh, Ghana, and Uganda; Working Paper 19; CGIAR Research Program on Climate Change, Agriculture and Food Security (CCAFS): Wageningen, The Netherlands, 2012.

131. Cherotich, V.K.; Saidu, O.; Bebe, B.O. Access to climate change information and support services by the vulnerable groups in semi-arid Kenya for adaptive capacity development. African Crop Sci. J. 2012, 20, 169-180.

132. Moghariya, D.P.; Smardon, R.C. Rural perspectives of climate change: A study from Saurastra and Kutch of Western India. Public Underst. Sci. 2014, 23, 660-677. [CrossRef]

133. Hansen, J.W.; Baethgen, W.E.; Osgood, D.E.; Ceccato, P.N.; Ngugi, R.K. Innovations in climate risk management: Protecting and building rural livelihoods in a variable and changing climate. J. Semi-Arid. Trop. Agric. Res. 2007, 4, 88-99.

134. Ballantyne, P.; Labelle, R.; Rudgard, S. Information and knowledge management: Challenges for capacity builders. Policy Manag. Br. 2000, 11. Available online: https://www.researchgate.net/profile/Stephen-Rudgard/publication/2650 72732_Information_and_Knowledge_Management_Challenges_for_Capacity_Builders/links/54ac89310cf23c69a2b7e887 /Information-and-Knowledge-Management-Challenges-for-Capacity-Builders.pdf (accessed on 10 September 2021).

135. Roncoli, C.; Jost, C.; Kirshen, P.; Sanon, M.; Ingram, K.T.; Woodin, M.; Somé, L.; Ouattara, F.; Sanfo, B.J.; Sia, C.; et al. From accessing to assessing forecasts: An end-to-end study of participatory climate forecast dissemination in Burkina Faso (West Africa). Clim. Chang. 2009, 92, 433-460. [CrossRef]

136. Kogan, F.N. Global drought watch from space. Bull. Am. Meteorol. Soc. 1997, 78, 621-636. [CrossRef]

137. Egeru, A. Role of indigenous knowledge in climate change adaptation: A case study of the Teso Sub-Region, Eastern Uganda. Indian J. Tradit. Knowl. 2012, 11, 217-224.

138. Tambo, J.A.; Abdoulaye, T. Climate change and agricultural technology adoption: The case of drought tolerant maize in rural Nigeria. Mitig. Adapt. Strateg. Glob. Chang. 2012, 17, 277-292. [CrossRef]

139. Chinlampianga, M. Traditional Knowledge, Weather Prediction and Bioindicators: A Case Study in Mizoram, Northeastern India; NISCAIR-CSIR: New Delhi, India, 2011.

140. King, D.N.T.; Skipper, A.; Tawhai, W.B. Environmental knowledge of local weather and climate change in Aotearoa-New Zealand. Clim. Chang. 2008, 90, 385-409. [CrossRef]

141. Chand, S.S.; Chambers, L.E.; Waiwai, M.; Malsale, P.; Thompson, E. Indigenous knowledge for environmental prediction in the Pacific Island countries. Weather. Clim. Soc. 2014, 6, 445-450. [CrossRef]

142. Speranza, C.I.; Kiteme, B.; Ambenje, P.; Wiesmann, U.; Makali, S. Indigenous knowledge related to climate variability and change: Insights from droughts in semi-arid areas of former Makueni District, Kenya. Clim. Chang. 2010, 100, 295-315. [CrossRef]

143. Anik, S.I.; Khan, M.A.S.A. Climate change adaptation through local knowledge in the north eastern region of Bangladesh. Mitig. Adapt. Strateg. Glob. Chang. 2012, 17, 879-896. [CrossRef]

144. Leonard, S.; Parsons, M.; Olawsky, K.; Kofod, F. The role of culture and traditional knowledge in climate change adaptation: Insights from East Kimberley, Australia. Glob. Environ. Chang. 2013, 23, 623-632. [CrossRef]

145. Green, D.; Billy, J.; Tapim, A. Indigenous Australians' knowledge of weather and climate. Clim. Chang. 2010, 100, 337-354. [CrossRef]

146. Huntington, H.; Callaghan, T.; Fox, S.; Krupnik, I. Matching traditional and scientific observations to detect environmental change: A discussion on Arctic terrestrial ecosystems. AMBIO J. Hum. Environ. 2004, 33, 18-23. [CrossRef]

147. Asrat, P.; Simane, B. Farmers' perception of climate change and adaptation strategies in the Dabus watershed, North-West Ethiopia. Ecol. Process. 2018, 7, 1-13. [CrossRef]

148. Nelson, S.; Huyer, S. A Gender-Responsive Approach to Climate-Smart Agriculture: Evidence and Guidance for Practitioner; CGIAR Research Program on Climate Change, Agriculture and Food Security (CCAFS): Copenhagen, Denmark, 2016.

149. Jost, C.; Kyazze, F.; Naab, J.; Neelormi, S.; Kinyangi, J.; Zougmore, R.; Aggarwal, P.; Bhatta, G.; Chaudhury, M.; Tapio-Bistrom, M.-L.; et al. Understanding gender dimensions of agriculture and climate change in smallholder farming communities. Clim. Dev. 2016, 8, 133-144. [CrossRef]

150. Nyantakyi-Frimpong, H.; Bezner-Kerr, R. The relative importance of climate change in the context of multiple stressors in semi-arid Ghana. Glob. Environ. Chang. 2015, 32, 40-56. [CrossRef] 
151. Assan, E.; Suvedi, M.; Schmitt Olabisi, L.; Allen, A. Coping with and adapting to climate change: A gender perspective from smallholder farming in Ghana. Environments 2018, 5, 86. [CrossRef]

152. Dietz, A.J.; van Haastrecht, A.; Kotomei, A. Rapid Rural Appraisal in Kenya's Wild West: Economic Change and Market Integration in Alale Location, West Pokot District; University of Nairobi: Nairobi, Kenya, 1982.

153. Nangulu, A.K. Food Security and Coping Mechanisms in Marginal Areas: The Case of West Pokot, Kenya, 1920-1995; African Studies Centre: Leiden, The Netherlands, 2009.

154. MoALF. Climate Risk Profile for West Pokot; Kenya County Climate Risk Profile Series; The Kenya Ministry of Agriculture, Livestock and Fisheries (MoALF): Nairobi, Kenya, 2016.

155. Drought Hit Residents of West Pokot Appeal for Water, Relief Food. Daliy Nation. Available online: https:/ / nation.africa/kenya/ counties/west-pokot/West-Pokot-drought/3444836-3620386-3rgtpp/index.html. (accessed on 20 January 2017).

156. Lim, B.; Spanger-Siegfried, E.; Burton, I.; Malone, E.; Huq, S. Adaptation Policy Frameworks for Climate Change: Developing Strategies, Policies and Measures, 1st ed.; United Nations Development Programme (UNDP): New York, NY, USA; Cambridge University Press: Cambridge, UK, 2005; 268p, ISBN 9780521617604.

157. Harrison, G.A. Famine. Available online: https://agris.fao.org/agris-search/search.do?recordID=US9001640 (accessed on 10 September 2021). 